\title{
Studies on estrogen receptor (ER) $\alpha$ and $\beta$ responses on gene regulation in peripheral blood leukocytes in vivo using selective ER agonists
}

\author{
Denis Stygar, Britt Masironi, Håkan Eriksson and Lena Sahlin \\ Division for Reproductive Endocrinology, Department of Woman and Child Health, Karolinska Institutet, Karolinska University Hospital Solna, Q2:08, S-171 76 \\ Stockholm, Sweden \\ (Requests for offprints should be addressed to L Sahlin; Email: lena.sahlin@ki.se)
}

\begin{abstract}
Major reproductive events such as menstruation, ovulation, implantation, and cervical ripening are characterized by an increased number of invading leukocytes in the tissues. Sex steroid hormones, particularly estrogens, play an important role in these dynamic changes in the female reproductive tract. Estrogens have also been implicated in the pathogenesis of many common pathological conditions associated with leukocyte infiltration and immunological dysfunction, such as autoimmune diseases and atherosclerosis. Although the two estrogen receptor (ER) subtypes, ER $\alpha$ and $\mathrm{ER} \beta$, have been found in different leukocyte populations in tissues and in peripheral blood, there is still very little known about functional activity and importance of ERs in blood cells. To elucidate the different roles for $\mathrm{ER} \alpha$ and $\mathrm{ER} \beta$ in peripheral blood leukocytes, we used microarray gene expression profiling of rat peripheral blood
\end{abstract}

leukocytes subjected to in vivo treatment with estradiol $\left(\mathrm{E}_{2}\right)$, the selective ER $\alpha$ agonist $4,4^{\prime}, 4^{\prime \prime}$-(4-propyl-[1H]-pyrazole1,3,5-triyl)trisphenol (PPT), and the selective $\operatorname{ER} \beta$ agonist 2,3-bis(4-hydroxyphenyl)-propionitrile (DPN). We report the identification of genes that were commonly regulated by $E_{2}$, PPT, and DPN, and genes that were regulated either by the ER $\alpha$ or ER $\beta$ agonist. Further confirmatory analyses of the selected regulated genes 12-lipoxygenase, fibulin-1, furin, and calgranulin $\mathrm{B}$ are also presented. These results were then compared with those from the uterine tissue of the same animals. Our study demonstrates that peripheral blood leukocytes are responsive to estrogens. $E_{2}$ and selective $E R \alpha$ and $E R \beta$ agonists regulate a number of genes that may contribute to inflammation and remodeling of the extracellular matrix.

Journal of Endocrinology (2007) 194, 101-119

\section{Introduction}

Estrogens play an important role in many normal and pathological conditions associated with leukocyte infiltration. These conditions include dynamic changes in the female reproductive tract as well as autoimmune and cardiovascular diseases.

The majority of autoimmune diseases have higher prevalence in females than in males (Druckmann 2001). The activity of many diseases, such as multiple sclerosis and rheumatoid arthritis, decreases during pregnancy, most profoundly during the third trimester when the plasma estrogen level is highest (Whitacre 2001). Therefore, the sex steroid hormones, primarily estrogens, have been suggested to be responsible for the sex difference in prevalence and presentation of autoimmune diseases. Cardiovascular disorders, such as atherosclerosis, and autoimmune diseases are characterized by leukocyte infiltration and immunological dysfunction. It has been proposed that estrogens modify the course of these disorders by altering leukocyte functions in the tissue (McCrohon et al. 1999, Lang 2004).
Leukocyte infiltration is also a distinctive component in the physiological changes observed in the female reproductive tract, where remodeling of the extracellular matrix (ECM) occurs during menstruation, ovulation, implantation, and cervical ripening at parturition (Bokström et al. 1997). All these processes are under strict hormonal control, which may indicate that leukocyte function is affected by sex steroid hormones. Cervical ripening is characterized by inflammatory events, such as extravasation of neutrophils and macrophages (Stygar et al. 2001, Osman et al. 2003). Polymorphonuclear leukocytes and macrophages migrate from blood vessels and accumulate in the cervix uteri before parturition (Stygar et al. 2001). The hypothesis of the role of inflammatory cells in cervical ripening (Liggins 1981) has been supported by studies showing that cervical collagenases at parturition originate not only from resident fibroblasts of the cervical stroma but also from leukocytes invading the cervix (Osmers et al. 1992). In a previous study, we could show that the matrix metalloproteinase (MMP)-9 is present in the invading leukocytes of the human cervix (Stygar et al. 2002). MMPs are a large family of endopeptidases, which are 
responsible for the tissue remodeling and degradation of the ECM including collagens, elastins, gelatin, matrix glycoproteins, and proteoglycan (Verma \& Hansch 2007).

Estrogens and selective estrogen receptor (ER) modulators (SERMs) achieve their biological effect through binding to ERs (McDonnell 2006). The two ERs, ER $\alpha$ and $\operatorname{ER} \beta$, operate as inducible transcription factors. The ERs are also involved in the recruitment of co-regulator proteins and other protein-protein interactions, which can modify target gene transcription (McKenna et al. 1999, Diel 2002). $E R \alpha$ and $E R \beta$ are highly homologous in their DNA-binding domains and recognize the same estrogenresponsive element (ERE) on DNA. On the other hand, there is only about $60 \%$ homology in the ligand-binding domain, which leaves the possibility that certain ligands can be highly specific to only one subtype of ER (Enmark et al. 1997). ER $\alpha$ and $\mathrm{ER} \beta$ are differentially distributed in tissues and have overlapping, yet different, transcriptional effects. ER $\alpha$ more effectively activates a classical ERE than does $\operatorname{ER} \beta$, when stimulated with estradiol $\left(\mathrm{E}_{2} ; \mathrm{An}\right.$ et al. 1999). In contrast, in response to SERMs, ER $\beta$ is more effective at activating transcription via the activating protein (AP)-1 element when compared with ER $\alpha$ (Paech et al. 1997).

Several recent studies have aimed at elucidating the effects of selective ER ligands on immune responses. The beneficial effects, particularly of ER $\alpha$ ligands on suppression of experimental autoimmune encephalomyelitis have been shown (Elloso et al. 2005). $\mathrm{E}_{2}$ has been shown to decrease neutrophil infiltration in the lung following trauma hemorrhage in mice (Hildebrand et al. 2006), and a selective ER $\beta$ ligand (ERB-041) was shown to have potent anti-inflammatory activity in a rat model of arthritis (Follettie et al. 2006). The effects of $\mathrm{E}_{2}$, PPT, and DPN on estrogen-mediated immunomodulation were investigated in ovariectomized (ovx) mice, PPT but not DPN showed effects on thymus (Li \& McMurray 2006). Both ER subtypes have been found in different leukocyte populations in human tissues and in peripheral blood (Stygar et al. 2001, 2006, Molero et al. 2002). Still, the functional activity and importance of ERs in blood cells are principally unknown. To investigate the functional roles for $\operatorname{ER} \alpha$ and $\operatorname{ER} \beta$ in peripheral blood leukocytes, we used microarray gene expression profiling of rat peripheral blood leukocytes subjected to in vivo treatment with $\mathrm{E}_{2}$, the selective $\mathrm{ER} \alpha$ agonist 4,4',4" -(4-propyl-[1H]-pyrazole-1,3,5-triyl)trisphenol (PPT), and the selective ER $\beta$ agonist 2,3-bis(4hydroxyphenyl)-propionitrile (DPN; Harrington et al. 2003). We report the identification of genes that were commonly regulated by $\mathrm{E}_{2}$ and the selective agonists, and genes that were regulated either by the $\mathrm{ER} \alpha$ or $\mathrm{ER} \beta$ agonist. Further confirmatory analyses of the selected regulated genes 12-lipoxygenase (12-lox), fibulin-1, furin, and calgranulin $B$ are also presented.

\section{Materials and Methods}

\section{Animals and treatments}

Thirty-two 8-week-old female Sprague-Dawley rats were obtained from Scanbur BK AB (Sollentuna, Sweden) and housed for 14 days under standard conditions. The animals were housed four per cage with unlimited access to food (standard pellet diet) and water. The animal room was maintained at $21-23{ }^{\circ} \mathrm{C}$ with a $12-\mathrm{h}$ light period. On day 0 , the animals were ovx. Groups of eight animals ( $\sim 250 \mathrm{~g} \mathrm{bw})$ were s.c. administered $300 \mu \mathrm{l}$ of either $5.0 \mu \mathrm{g} \mathrm{E}_{2}$ or $1.25 \mathrm{mg}$ PPT or $3.125 \mathrm{mg}$ DPN or vehicle on day 14 . The animals were killed $18 \mathrm{~h}$ after treatment. The doses of PPT and DPN were chosen by comparing data on the activity of the agonists in mouse and rat uterus as reported before (Harris et al. 2002, Frasor et al. 2003, Lee et al. 2005). During the preparation of this article, a paper describing the effects by $\mathrm{E}_{2}$, PPT, and DPN on the immune functions in mice was published. In that paper, the authors specify doses in the same range as ours $(\mathrm{Li}$ \& McMurray 2006). The study was approved by the Northern Stockholm Ethical Committee on Animal Care.

\section{Hormones}

$17 \beta-E_{2}$ was purchased from Sigma Co., and dissolved in 99.5\% ethanol at a high concentration and then diluted with 50:50 DMSO:PBS to the proper concentration. The final concentration of ethanol was $<2 \%$ in the injections. PPT and DPN were bought from Tocris Cookson, via Bio Nuclear, Bromma, Sweden. These substances were dissolved in DMSO and then diluted with PBS, until the proper concentration and the vehicle was DMSO:PBS 50:50. The control group $(\mathrm{OvxC})$ was injected with the vehicle.

\section{$R N A$ isolation}

Blood was collected from vena cava in PAXgene Blood RNA tubes (PreAnalytix, Hombrechtikon, Switzerland). A volume of $2.5 \mathrm{ml}$ of blood was collected in each tube and two tubes were obtained from each animal. Prior to RNA isolation, the blood samples were incubated in the tubes for $24 \mathrm{~h}$ at room temperature (RT) to achieve complete lysis. Total RNA was purified according to the manufacturer's protocol. The quality and concentration of the RNA were assessed with Agilent Bioanalyzer (Agilent Technologies, Santa Clara, CA, USA) and Nanodrop 1000 Spectrophotometer (NanoDrop Technologies, Wilmington, DE, USA). Five RNA samples of highest quality were selected from each treatment group for microarray gene expression analysis.

The uterine tissue was placed in RNA stabilization solution (RNAlater, Ambion, Austin, TX, USA) immediately after collection and stored at $-20^{\circ} \mathrm{C}$. Total RNA from $20 \mathrm{mg}$ uterine tissue from each animal was purified with the RNAeasy kit (Qiagen) according to a procedure 
recommended by manufacturer for RNA isolation from fibrous tissues.

\section{Microarray slides}

We used spotted 70-mer oligonucleotide microarrays with 27744 probes from the Operon AROS collection printed in duplicate. The slides were produced by the Swegene DNA Microarray Resource Center, Department of Oncology, Lund University.

\section{cDNA synthesis, labeling, and hybridization}

cDNA was synthesized from $20 \mu \mathrm{g}$ RNA from each sample and reference, and labeled with $\mathrm{Cy} 3$ and $\mathrm{Cy} 5$ using the CyScribe First-Strand cDNA labeling kit (Amersham Biosciences). RT was primed with anchored oligo(dT) and random primers and catalyzed by CyScript reverse transcriptase in the presence of $\mathrm{Cy} 3$ or $\mathrm{Cy} 5$ dye-labeled nucleotide dUTP. After RT, the remaining RNA templates were degraded by alkaline hydrolysis treatment using $\mathrm{NaOH}$ followed by neutralization with HEPES. Labeled cDNA was purified with QIAquick PCR purification kit (Qiagen). Dye incorporation was estimated using NanoDrop 1000 spectrophotometer. Comparisons were performed on five biological replicates in each treatment group, with three samples in one dye set and two in the opposite, i.e. a dye-swap was done for all treatments. A common reference (vehicle control) was used in all hybridizations.

Microarray slides were incubated with $60 \mu \mathrm{l}$ pre-hybridization mixture in a humidified chamber in a water bath at $42{ }^{\circ} \mathrm{C}$ for $45 \mathrm{~min}$. The pre-hybridization mixture contained $15 \mu \mathrm{l} 20 \times$ SSC, $6 \mu \mathrm{l} 50 \times$ Denhardt's solution, $1 \cdot 2 \mu \mathrm{l}$ RNA $(1 \mu \mathrm{g} / \mu \mathrm{l}), 3 \mu \mathrm{l} 10 \%$ SDS, $4 \cdot 8 \mu \mathrm{l} \mathrm{ddH}_{2} \mathrm{O}$, and $30 \mu \mathrm{l}$ formamide. After pre-hybridization, each slide was washed

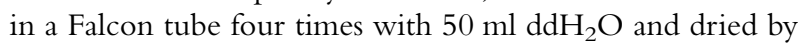
centrifugation for $10-15 \mathrm{~s}$ in Microarray High-Speed centrifuge MHC220V (TeleChem International, Sunnyvale, CA, USA). The blocking reagents poly $\mathrm{d}(\mathrm{A})$ (Amersham Biosciences) and yeast tRNA (Sigma) were added to the cDNA samples in order to reduce non-specific hybridization. Hybridization was performed in a Hybridization Cassette ArrayIt (TeleChem) water bath at $42{ }^{\circ} \mathrm{C}$ for $18 \mathrm{~h}$. The hybridization solution contained $20 \mu \mathrm{g}$ labeled cDNA, $15 \mu \mathrm{l}$ formamide, $7 \cdot 5 \mu \mathrm{l} 4 \times$ hybridization buffer, $20 \mu \mathrm{g}$ yeast

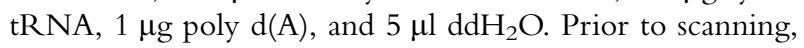
the slides were washed with $1 \times, 0 \cdot 2 \times$, and $0 \cdot 1 \times$ SSC and dried by centrifugation for $10-15 \mathrm{~s}$.

\section{Scanning and image analysis}

Slides were scanned twice at $10 \mu \mathrm{m}$ resolution with decreasing pmt voltages using a Scanarray Express HT scanner (Perkin-Elmer, Zaventem, Belgium). Image analysis was performed using a SpotReader (Niles Scientific, Portola Valley, CA, USA). Data files were processed using $R$ ( $R$ development core team, 2004, http://www.r-project.org) and packages from Bioconductor (www.bioconductor.org). Background was estimated from a local spot background using a $3 \times 3$ window minimum and shifted in a way that $<$ $1 \%$ of the spots on each array had negative background subtracted intensities.

Data from each array were normalized using a nonstratified loess fit of log ratios on average intensities (Yang et al. 2002). Data points from spots near saturation were excluded from the loess fit. Following normalization, data from high pmt voltage scans were combined with data from lower pmt voltage scans by replacing data of probes near saturation in any of the high pmt voltage scans with the corresponding data from the lower pmt voltage datasets. Contrasts between samples of interest and spread measures were calculated using Limma software (http://bioinf.wehi.edu.au/limma; Smyth 2004) on a reduced dataset where probes with less than four spots above an average logged intensity of 9 in all three treatments had been removed. Probes were ordered by the false discovery rate (FDR) reported by Limma when using method FDR as correction for multiple testing (Benjamini \& Hochberg 1995).

\section{The gene ontology functional and enrichment analyses}

Gene ontology functional and term enrichment analyses were carried out using the DAVID tool (http://david.abcc.ncifcrf. gov/) and by applying EASE statistics for the enrichment analysis (Hosack et al. 2003). First, for each probe on the array, the Ensembl IDs provided by the array probe manufacturer were converted to Entrez Gene IDs using the BioMart tool (http://www.biomart.org). Next, for each set of genes (corresponding to either up- or down-regulated genes by the $\mathrm{E}_{2}$, PPT, or DPN treatments, i.e. six lists in total), the co-occurrence of gene ontology functional terms in the annotations were compared with the expected frequencies derived by using a background list corresponding to all probes printed on the array. The results are presented in supplementary Tables 1 and 2 (see supplementary data in the online version of the Journal of Endocrinology at http://joe. endocrinology-journals.org/content/vol194/issue2). A term was considered significantly enriched if the $P$ value was $<$ 0.05 and if at least two genes mapped to the term.

\section{ArrayExpress}

The entire microarray dataset has been deposited into the ArrayExpress microarray data repository using accession numbers A-MEXP-743 (70-mer microarray platform) and A-TABM-269 (gene expression dataset).

\section{Reverse Transcription (RT)}

Total RNA $(2 \mu \mathrm{g})$ from each leukocyte and uterus sample were reverse transcribed at $37^{\circ} \mathrm{C}$ for $60 \mathrm{~min}$ in a final volume of $20 \mu \mathrm{l}$ with a reaction mixture (Qiagen $\mathrm{GmbH}$ ) containing 
$1 \times$ RT buffer, dNTP mix $(0.5 \mathrm{mM}$ each dNTP), $600 \mathrm{ng}$ random primers (Invitrogen), 10 units RNase inhibitor (Superase-In, Ambion), and $4 \mathrm{U}$ of Omniscript reverse transcriptase (Qiagen).

Real-time PCR for 12-lox, fibulin-1, furin, and calgranulin B

Real-time PCR was performed in a DNA Engine Opticon 2 System (MJ Research, Waltham, MA, USA). For PCR, the cDNAs corresponding to $100 \mathrm{ng}$ RNA were added to $10 \mu \mathrm{l}$ Quantitect SYBR ${ }^{\circledR}$ Green PCR mix (Qiagen) containing HotStarTaq DNA polymerase, PCR buffer, dNTP mixture, and $0.3 \mu \mathrm{M}$ of each oligonucleotide primer in a final volume of $20 \mu \mathrm{l}$. The reactions were performed in opaque white $0.2 \mathrm{ml}$ low-profile strip tubes sealed with optical flat caps (TLS-0851, TCS-0803, MJ Research). After initial incubation for $15 \mathrm{~min}$ at $95^{\circ} \mathrm{C}$, the samples were subjected to 44 cycles of $10 \mathrm{~s}$ at $94{ }^{\circ} \mathrm{C}, 15 \mathrm{~s}$ at $57^{\circ} \mathrm{C}$, and $20 \mathrm{~s}$ at $72{ }^{\circ} \mathrm{C}$ with a final extension step at $72{ }^{\circ} \mathrm{C}$ for $5 \mathrm{~min}$. All reactions were performed in duplicates. The amount of PCR products for 12-lox, fibulin-1, furin, and calgranulin $B$ in peripheral blood and uterus samples increased linearly up to $25-28$ cycles. The purity of PCR products was confirmed by a melting curve analysis in all experiments (data not shown). Oligonucleotide primers for 12-lox, fibulin-1, fibulin-1C, fibulin-1D, furin, calgranulin $B$ and HPRT are listed in Table 1. All primers were designed to span an intron/exon boundary or to flank an intron; thus, amplification of contaminating DNA was eliminated. Each PCR assay included a negative control containing RNA sample without RT.

\section{Quantification of $m R N A$}

To standardize the quantification method, hypoxanthine guanine phosphoribosyl transferase (HPRT) was selected out of several tested housekeeping genes as an invariable internal control. The control gene, 12-lox, fibulin-1, furin, and calgranulin B mRNAs were amplified under the same conditions. The PCR amplification rate and the cycle threshold $(\mathrm{Ct})$ values were related to a standard curve using Opticon Monitor 2.0 software (MJ Research). The values of relative expression of genes of interest were normalized against the HPRT product.

\section{Protein extraction}

Peripheral blood leukocytes and uterus were stored at $-20{ }^{\circ} \mathrm{C}$ in RNAlater stabilization solution (Ambion). Leukocytes (3$\left.4 \times 10^{6}\right)$ and uterus tissue $(20-40 \mu \mathrm{g})$ were disrupted, respectively, in 300 and $400 \mu \mathrm{l}$ ice-cold cell lysis buffer containing $50 \mathrm{mM}$ Tris- $\mathrm{HCl}, 150 \mathrm{mM} \mathrm{NaCl}, 1 \%$ Triton-X, and $5 \mathrm{mM}$ EDTA, as well as a protease inhibitor (Complete Mini, Roche). Protein concentrations were measured by Lowry protein assay with BSA as a standard (Lowry et al. 1951).

\section{Western blot}

Leukocyte samples from two ovx rats and from two ovx- and $17 \beta-E_{2}$-treated rats from a previous experiment were available for western blot. The leukocyte samples from the animals in the present study were not obtainable for protein preparation, since all material was used for RNA extraction for the microarray experiment, and later also for PCR. However, protein samples from all the uteri of the animals in the present experiment were used. Protein extract $(10 \mu \mathrm{g})$ from each sample was resolved on $7 \cdot 5 \%$ polyacrylamide gels for $12-1$ ox, whereas $60 \mu \mathrm{g}$ samples were run on $15 \%$ polyacrylamide gels for calgranulin B, in Mini-Protean II cell (Bio-Rad Laboratories) using Tris-glycine buffers. Proteins were transferred from the gels to polyvinylidene fluoride (PVDF) membranes (Amersham) by electroblotting. Molecular weight marker was purchased from Bio-Rad (Precision Plus protein

Table 1 Oligonucleotide primers used for real-time PCR

\begin{tabular}{|c|c|c|c|}
\hline & $\begin{array}{l}\text { Accession no. or } \\
\text { reference }\end{array}$ & Primer & Position \\
\hline \multicolumn{4}{|l|}{ Gene } \\
\hline \multirow[t]{2}{*}{ 12-Lipoxygenase } & NM_031010 & Forward GAAGCTGCTACGACССТGTC & Exon 1, bp 114-133 \\
\hline & & Reverse GGCGTCATCCGTGAGATAAT & Exon 2, bp 231-212, product 118 bp \\
\hline \multirow[t]{2}{*}{ Fibulin-1 } & XM_243637 & Forward CAAGGAGTGCAGGATGGTC & Exon $3-4$, bp 304-322 \\
\hline & & Reverse TGGTCTCGAGGCTACTGTTG & Exon 4, bp 440-421, product 137 bp \\
\hline \multirow[t]{2}{*}{ Fibulin-1C } & Haendler et al. (2004) & Forward CTGCAGACACCCGCTGTG & Exon 14, bp 1694-1712 \\
\hline & & Reverse AGCGGTGATGGCCAGCTG & Exon 15 , bp 1875-1858, product 182 bp \\
\hline \multirow[t]{2}{*}{ Fibulin-1D } & XM_243637 & Forward GGCTGACATCATCTTCGACA & Exon 16, bp 2023-2042 \\
\hline & & Reverse AGCTTCAGGACGGCATAAAA & Exon 17 , bp 2163-2144, product 141 bp \\
\hline \multirow[t]{2}{*}{ Furin } & NM_019331 & Forward TAGCTGCCAGACCACATGAC & Exon 13-14, bp 1990-2009 \\
\hline & & Reverse GGTCAGCGTCCCATAGTTGT & Exon $14-15,2135-2116$, product 146 bp \\
\hline \multirow[t]{2}{*}{ Calgranulin B } & NM_053587 & Forward GCTCСТTAGCTTTGAGCAAGA & Exon $1-2$, bp 9-29 \\
\hline & & Reverse TTTCTTTGAАTTCСGССТTG & Exon 2, bp 152-133, product 144 bp \\
\hline \multirow[t]{2}{*}{ HPRT } & NM_012583 & Forward CTCATGGACTGATTATGGACAGGAC & Exon $2-3$, bp 179-203 \\
\hline & & Reverse GCAGGTCAGCAAAGAACTTATAGCC & Exon 3, bp 301-277, product 123 bp \\
\hline
\end{tabular}


standard, Bio-Rad Laboratories). All uterine samples from the experiment were analyzed by western blot, run two from each group in four consecutive gels.

After blocking in 5\% non-fat milk (NFM, Bio-Rad Laboratories) in TBS-Tween $(0 \cdot 1 \%)$ for $60 \mathrm{~min}$ at room temperature, the membranes were incubated overnight at $4{ }^{\circ} \mathrm{C}$ with primary antibodies. The dilution of the primary antibodies was $1: 15002.5 \%$ NFM in TBS-T for the 12-lox polyclonal antiserum (rabbit anti-mouse, Cat. No. 160304, Cayman Chemical, Ann Arbor, MI, USA) and 1:100 in 2.5\% NFM in TBS-T for the calgranulin B polyclonal antibody (goat anti-mouse, Cat. No. sc-8115, Santa Cruz Biotechnology, Santa Cruz, CA, USA). Membranes were washed twice for $5 \mathrm{~min}$ in TBS-T and incubated for $60 \mathrm{~min}$ at RT with AP-conjugated anti-rabbit secondary antibody (Sigma sc-3687) diluted 1:15000 in 2.5\% NFM in TBS-T or with AP-conjugated anti-goat secondary antibody (Cat. No. sc2310, Santa Cruz Biotechnology) diluted $1: 500$ in $2.5 \%$ NFM in TBS-T. This was followed by washing in TBS-T and developing the membranes in NBT/BCIP (Sigma). All incubations were performed on a shaking platform.

The bands from the 12-lox blots were captured and analyzed using the Gel Doc 2000 Gel Documentation System (Bio-Rad Laboratories).

\section{Statistical analyses}

Data from the relative quantification of real-time PCR products and western blot were analyzed with ANOVA on ranks (Kruskal-Wallis test). Significance levels were calculated using Dunn's test. Differences at $P<0.05$ were considered significant.

\section{Results}

\section{Uterine weights}

The uterine weights of the rats were measured to determine the estrogenic response from the treatment. The uterine weights (in $\mathrm{g} \pm$ s.E.M.) of the animals in the $\mathrm{E}_{2}$ and PPT groups $(0 \cdot 169 \pm 0.009$ and $0.205 \pm 0.009$ respectively) were significantly increased when compared with the OvxC group $(0 \cdot 120 \pm 0 \cdot 007)$, while the DPN group was unaffected $(0 \cdot 120 \pm 0 \cdot 005)$. This confirms that ER $\alpha$ mediates the effect on uterine weight.

\section{Genes regulated by $E_{2}, P P T$, and DPN}

The identification of genes reproducibly regulated by the treatments is based on the low FDR criterion. We considered the regulated genes to be those with an absolute $t$-value (a ratio of Log2-expression level to its standard error) higher than or equal to 3 (Fig. 1). Under these conditions, we found 54 up-regulated and 96 down-regulated genes. As shown in the Venn diagrams, most of the induced or suppressed genes identified by microarray analysis were unique in each
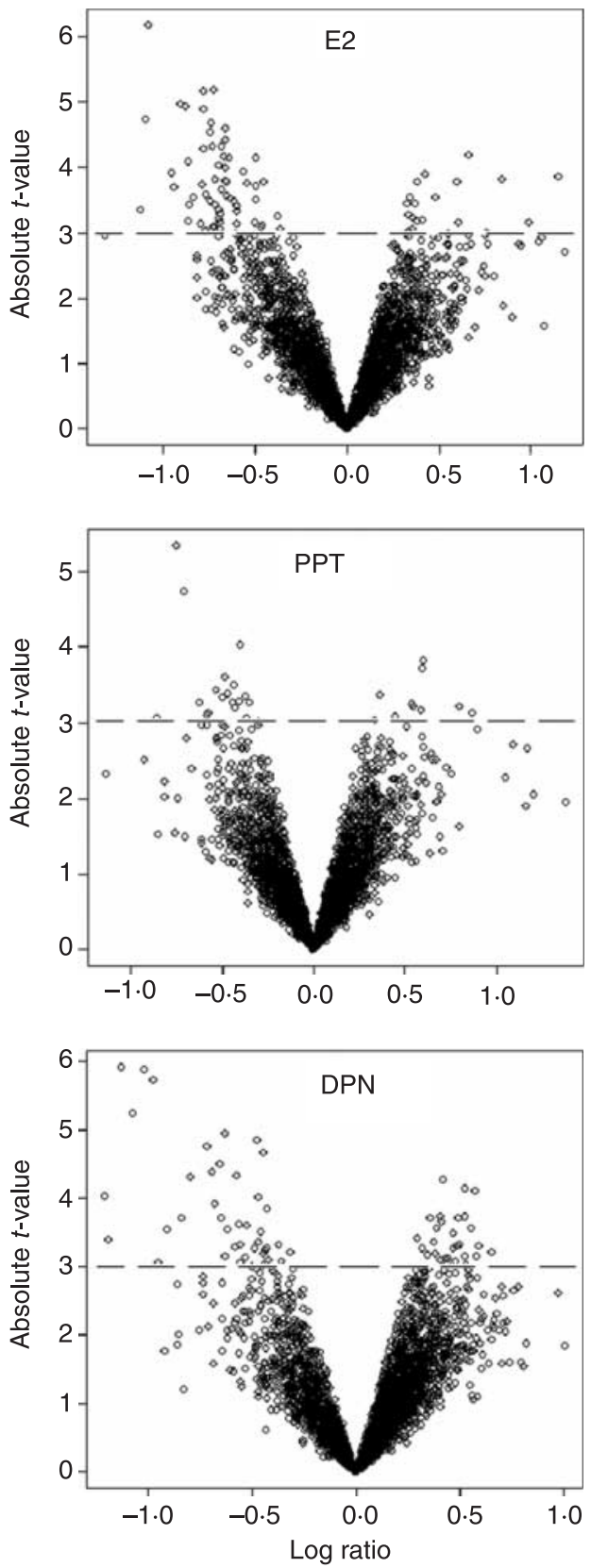

Figure 1 Scatter plots of an absolute $t$-value (a ratio of Log2expression level to its standard error), when testing for difference between each treatment and control, plotted versus mean log difference between treatment and control. Genes with statistically significant differential expression according to moderated $t$-statistics lie above a horizontal threshold line.

treatment group. Only a few genes were commonly regulated by two or more treatments (Fig. 2). We observed more negatively regulated than induced genes in all treatment groups. The selective ER $\beta$ agonist DPN produced considerably greater transcriptional response in leukocytes when compared with the selective $\operatorname{ER} \alpha$ agonist PPT (Fig. 2). 

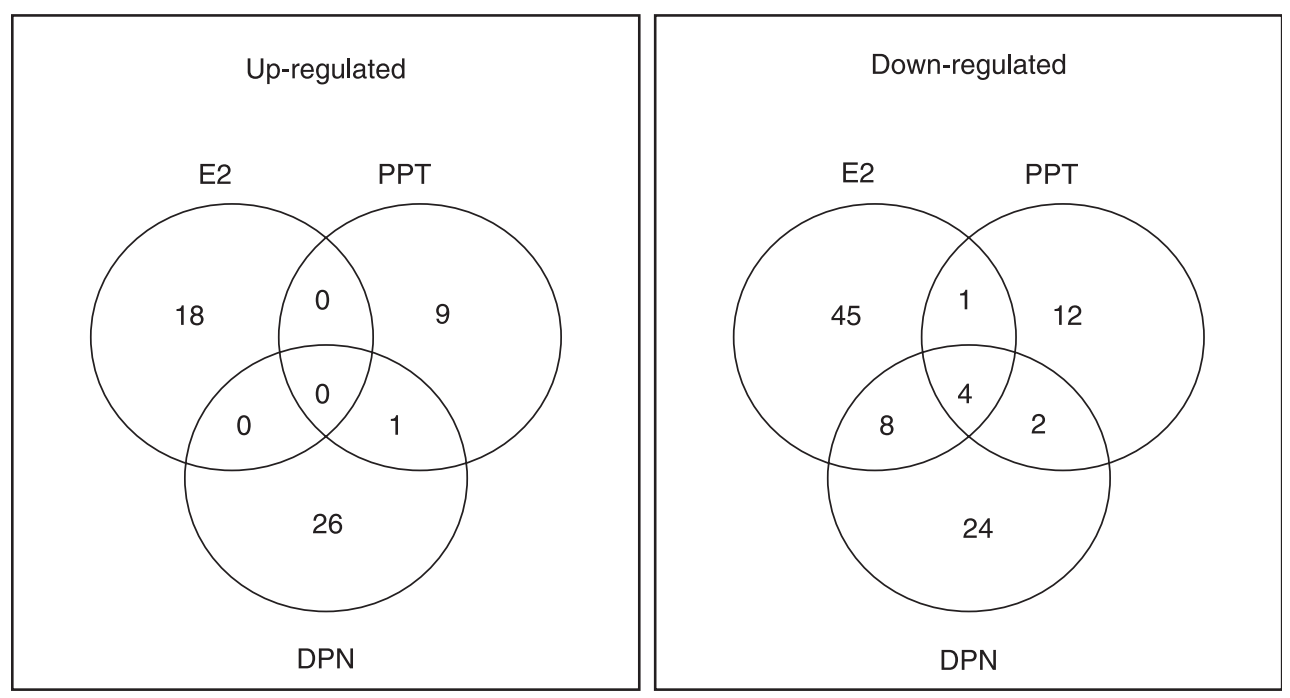

Figure 2 Number of common and unique up- and down-regulated probes with an absolute $t$-value more than or equal to 3 when testing for difference between each treatment and control.

Tables 2-4 list genes that were regulated by each treatment and had an absolute $t$-value more or equal to 3 . Among regulated genes identified by microarray, we selected a few genes that may be involved in the remodeling of ECM. Transcriptional profiles of the selected genes were also determined by real-time PCR. These genes were arachidonate 12-lox, fibulin-1, furin, and calgranulin $B$ (highlighted in bold in Tables 2-4).

\section{Functional categories and enrichment analyses}

Studies on the functional categories of the regulated genes revealed that these analyses were possible to do on downregulated genes for all treatments but in the case of up-regulated genes only after DPN treatment due to the limited number of genes that are up-regulated by the $\mathrm{E}_{2}$ and PPT treatments. What we find is that the majority of down-regulated genes, as well as the shared down-regulated genes, relate to 'cellular metabolism' and 'intracellular organelle/intracellular membrane-bound organelle/cytoplasm'. Comparing up- and down-regulated genes after DPN treatment shows that genes related to metabolism are regulated both ways, while 'cell death' is among the downregulated genes and 'immune response' and 'defense response' are among the up-regulated genes. In addition, genes related to 'metal ion binding' and 'cation binding' are down-regulated, while those associated with 'RNA binding' are up-regulated. Thus, there are both functional similarities and differences between up- and down-regulated genes after DPN treatment. For the functional categories of regulated genes on term basis, please see supplementary Table $1 \mathrm{a}-\mathrm{d}$.

The enrichment analysis is carried out for all gene ontology branches ('molecular function', 'biological processes', and 'cellular component') and KEGG pathways. The results of the analyses are reported in supplementary Tables $2 \mathrm{a}$ and $\mathrm{b}$, when enriched terms were found $(P<0 \cdot 1)$. Note that the Tables also contain terms that do not reach the statistical significance, but are close to $(0 \cdot 1>P>0 \cdot 05)$; these are written in italics. The general conclusion from this analysis is that the gene lists are too short for (gene ontology) term enrichment analysis. An exception to this is the group of genes down-regulated by $E_{2}$ treatment, for which multiple (mainly overlapping) terms are found (see supplementary Table 2 for details at http://joe. endocrinology-journals.org/content/vol194/issue2). Downregulation after $E_{2}$ treatment relates to $50 \%$ or more to 'binding' and 'cellular physiological process' $(P<0 \cdot 05)$. The most significantly affected functions were 'responses to oxidative stress' and 'oxygen and reactive oxygen species metabolism' $(P<0 \cdot 001)$ together with 'negative regulation of cellular physiological process' $(P<0 \cdot 01)$ and 'cellular metabolism' $(P=0 \cdot 01)$. PPT showed no significantly enriched terms among the down-regulated genes, but the terms closest to significance $(0=0.054$ and $0 \cdot 059$ respectively) were 'endosome' and 'intracellular transport'. Looking at DPN treatment, the significantly enriched terms for the down-regulated genes were those related to the terms 'Golgi network', 'intracellular', and 'transport vesicle'. The up-regulated genes were associated with the terms 'ribosome', 'cytosol', 'non-membrane bound organelles', and 'immune response'.

The enrichment analysis clearly shows that $\mathrm{E}_{2}$ primarily down-regulate genes associated with physiological processes, metabolism, and binding, while DPN down-regulate genes associated with the Golgi network and intracellular transport (supplementary Table 2a at http://joe.endocrinology-journals.org/content/vol194/issue2).

In addition, we find that up- and down-regulated genes after DPN treatment affect different functions; intracellular functions are down-regulated, while genes related to ribosomal functions and immune responses are up-regulated (supplementary Table 2b http://joe.endocrinology-journals. org/content/vol194/issue2). 
Table 2 Subset of genes regulated by estradiol in peripheral blood leukocytes

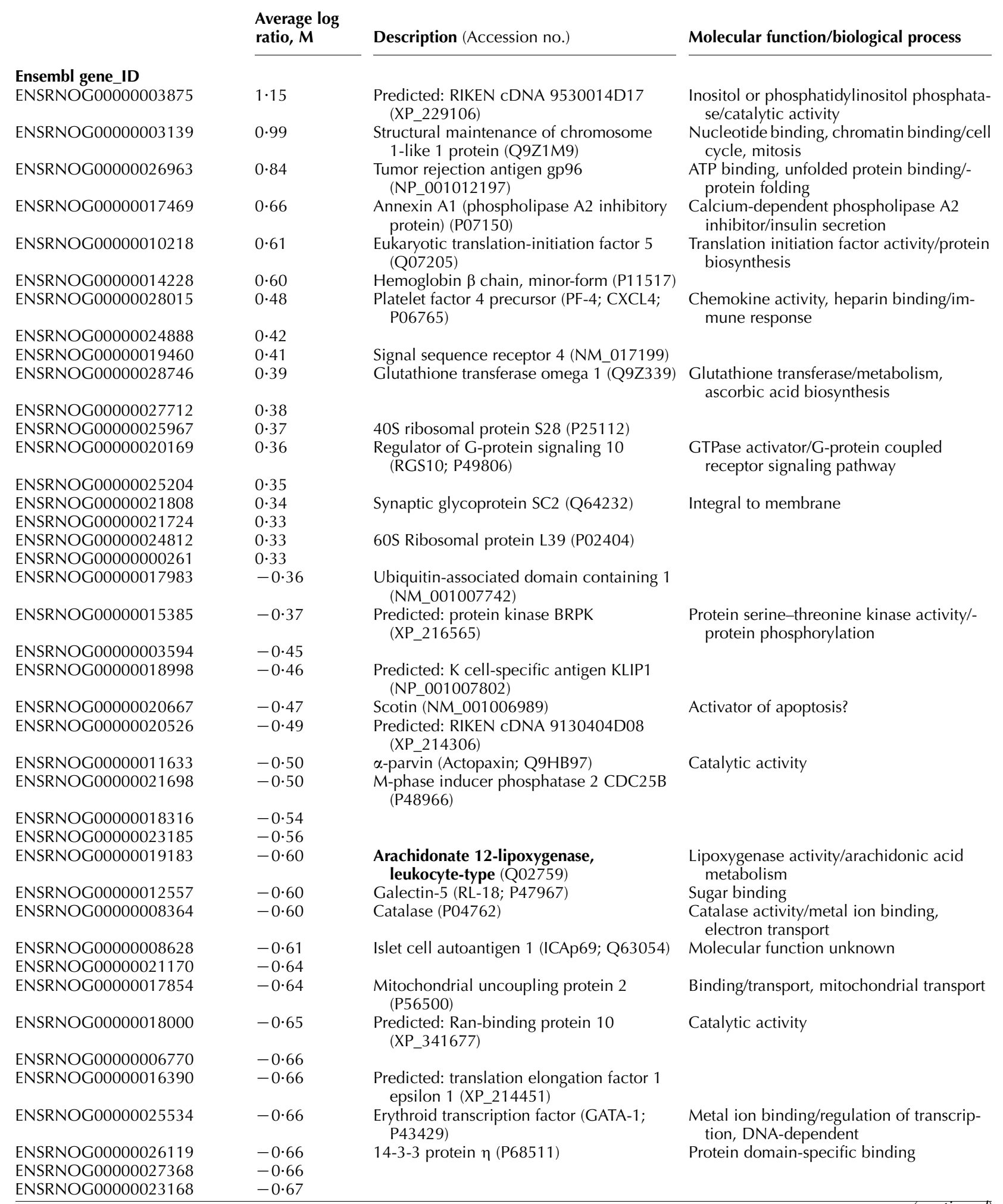


Table 2 Continued

\begin{tabular}{|c|c|c|c|}
\hline & $\begin{array}{l}\text { Average log } \\
\text { ratio, } M\end{array}$ & Description (Accession no.) & Molecular function/biological process \\
\hline ENSRNOG00000016150 & -0.68 & Predicted: IRFD2 (XP_217254) & \\
\hline ENSRNOG00000018325 & -0.69 & & Integral to membrane \\
\hline ENSRNOG00000014179 & $-0 \cdot 69$ & 40S ribosomal protein S2 (P27952) & $\begin{array}{l}\text { Structural constituent of ribosome/protein } \\
\text { biosynthesis }\end{array}$ \\
\hline ENSRNOG00000007921 & $-0 \cdot 69$ & $\begin{array}{l}\text { Heterogeneous nuclear ribonucleoprotein } \\
\text { M (Q62826) }\end{array}$ & RNA binding \\
\hline ENSRNOG00000025323 & $-0 \cdot 70$ & & \\
\hline ENSRNOG00000004169 & $-0 \cdot 70$ & $\begin{array}{l}\text { Predicted: fizzy-related protein } \\
\quad \text { (XP 243390) }\end{array}$ & Catalytic activity \\
\hline ENSRNOG00000010037 & $-0 \cdot 70$ & $\begin{array}{l}\text { Predicted: erythrocyte membrane protein } \\
\text { band } 4 \cdot 1 \text { (XP_232771) }\end{array}$ & $\begin{array}{l}\text { Actin binding/catalytic activity, cytoskele- } \\
\text { ton organization }\end{array}$ \\
\hline ENSRNOG00000017671 & $-0 \cdot 72$ & Ras GTPase-activating protein 3 (Q9QYJ2) & GTPase activator activity/catalytic activity \\
\hline ENSRNOG00000009640 & $-0 \cdot 72$ & $\begin{array}{l}\text { Proteasome inhibitor PI31 subunit } \\
\text { (Q5XIU5) }\end{array}$ & Protein complex \\
\hline ENSRNOG00000025023 & $-0 \cdot 72$ & $\begin{array}{l}\text { Signal transducer and activator of tran- } \\
\text { scription 6, STAT6 (O70429) }\end{array}$ & $\begin{array}{l}\text { Transcription factor activity/regulation of } \\
\text { transcription }\end{array}$ \\
\hline ENSRNOG00000007971 & $-0 \cdot 72$ & WW domain-binding protein 2 (Q8R478) & \\
\hline ENSRNOG00000020235 & -0.73 & $\begin{array}{l}\text { Heterogeneous nuclear ribonucleoprotein } \\
\text { L (NP 116008) }\end{array}$ & Nucleic acid binding \\
\hline ENSRNOG00000011489 & $-0 \cdot 73$ & $\begin{array}{l}\text { Predicted: RIKEN cDNA C030046I01 } \\
\quad(\text { XP_343169) }\end{array}$ & Nucleic acid binding \\
\hline ENSRNOG00000018053 & $-0 \cdot 74$ & Predicted: ferrochelatase (XP_341623) & Ferrochelatase activity/heme biosynthesis \\
\hline ENSRNOG00000022927 & $-0 \cdot 74$ & & \\
\hline ENSRNOG00000019349 & $-0 \cdot 74$ & $\begin{array}{l}\text { Splicing factor 3a, subunit } 2 \\
\text { (NP_001011986) }\end{array}$ & Nucleic acid binding, zinc ion binding \\
\hline ENSRNOG00000018396 & $-0 \cdot 76$ & Pre-mRNA splicing factor 18 (Q9JKB8) & $\begin{array}{l}\text { Potassium channel inhibitor activity/RNA } \\
\text { splicing }\end{array}$ \\
\hline ENSRNOG00000020102 & $-0 \cdot 77$ & $\begin{array}{l}\text { Sirtuin } 2 \text { (silent mating type information } \\
\text { regulation 2; NP_001008369) }\end{array}$ & $\begin{array}{l}\text { DNA binding, chromatin silencing/regula- } \\
\text { tion of transcription }\end{array}$ \\
\hline ENSRNOG00000005480 & $-0 \cdot 78$ & DNA-binding protein A (Q62764) & $\begin{array}{l}\text { Single-stranded DNA binding/regulation of } \\
\text { transcription }\end{array}$ \\
\hline ENSRNOG00000019721 & $-0 \cdot 78$ & Predicted: yippee-like 3 (XP_215057) & \\
\hline ENSRNOG00000012206 & $-0 \cdot 78$ & $\begin{array}{l}\text { Predicted: Rab6 interacting protein } 1 \\
\quad \text { (XP 219270) }\end{array}$ & Nucleic acid binding/catalytic activity \\
\hline ENSRNOG00000020363 & $-0 \cdot 78$ & $\begin{array}{l}\text { Predicted: mediator of RNA polymerase II } \\
\text { subunit } 9 \text { (XP_214950) }\end{array}$ & Catalytic activity \\
\hline ENSRNOG00000015753 & $-0 \cdot 78$ & $\begin{array}{l}\text { Epsin-1 (EPS-15 interacting protein 1; } \\
\text { O88339) }\end{array}$ & Lipid binding/endocytosis \\
\hline ENSRNOG00000015762 & -0.79 & $\begin{array}{l}\text { Ankyrin repeat and BTB (POZ) domain } \\
\text { containing } 1 \text { (NP_001005902) }\end{array}$ & Protein binding \\
\hline ENSRNOG00000016185 & $-0 \cdot 83$ & & \\
\hline ENSRNOG00000020994 & $-0 \cdot 85$ & & Binding/transport \\
\hline ENSRNOG00000017871 & $-0 \cdot 86$ & Predicted: to Sidt2 protein (XP_236205) & Catalytic activity \\
\hline ENSRNOG00000009323 & $-0 \cdot 86$ & & \\
\hline ENSRNOG00000007946 & $-0 \cdot 88$ & Apoptosis regulator Bcl-X (P53563) & Caspase inhibitor activity/anti-apoptosis \\
\hline ENSRNOG00000011352 & $-0 \cdot 91$ & Furin precursor $(\mathrm{P} 23377)$ & $\begin{array}{l}\text { Calcium ion binding, proteolysis and } \\
\text { peptidolysis/catalytic activity }\end{array}$ \\
\hline ENSRNOG00000020951 & $-0 \cdot 94$ & Band 3 anion transport protein (P23562) & $\begin{array}{l}\text { Inorganic anion exchanger activity/anion } \\
\text { transport }\end{array}$ \\
\hline ENSRNOG00000018503 & -0.96 & Bcl-x short form (Q548R7) & Regulation of apoptosis \\
\hline ENSRNOG00000021248 & $-1 \cdot 08$ & M-phase inducer phosphatase 2 (P48966) & $\begin{array}{l}\text { Protein tyrosine phosphatase activity/cell } \\
\text { division }\end{array}$ \\
\hline ENSRNOG00000014137 & $-1 \cdot 10$ & Predicted: fibulin-1 precursor (XP_243637) & Calcium ion binding/catalytic activity \\
\hline ENSRNOG00000016984 & $-1 \cdot 12$ & $\begin{array}{l}\text { Predicted: hypothetical protein } \\
\text { D2Ertd391e (XP_342466) }\end{array}$ & \\
\hline
\end{tabular}


Table 3 Subset of genes regulated by 4,4',4"-(4-propyl-[1 $H]$-pyrazole-1,3,5-triyl)trisphenol in peripheral blood leukocytes

\begin{tabular}{|c|c|c|c|}
\hline & $\begin{array}{l}\text { Average log } \\
\text { ratio, } M\end{array}$ & Description (Accession no.) & Molecular function/biological process \\
\hline \multicolumn{4}{|l|}{ Ensembl gene_ID } \\
\hline ENSRNOG00000023887 & $0 \cdot 80$ & & \\
\hline ENSRNOG00000027225 & $0 \cdot 61$ & G6f protein (NP_001003691) & \\
\hline ENSRNOG00000022940 & $0 \cdot 60$ & & \\
\hline ENSRNOG00000010906 & $0 \cdot 59$ & $\begin{array}{l}\text { Small inducible cytokine A5 precursor } \\
\text { (CCL5) RANTES (P50231) }\end{array}$ & $\begin{array}{l}\text { Chemokine activity/chemotaxis, inflam- } \\
\text { matory response }\end{array}$ \\
\hline ENSRNOG00000021216 & $0 \cdot 54$ & $\begin{array}{l}\text { Predicted: peroxisomal biogenesis } \\
\text { factor 11b (NM_001025684) }\end{array}$ & \\
\hline ENSRNOG00000025440 & $0 \cdot 45$ & & \\
\hline ENSRNOG00000023720 & $0 \cdot 37$ & $\begin{array}{l}\text { Predicted: neurotrimin precursor } \\
\quad \text { (GP65; Q62718) }\end{array}$ & Protein binding/cell adhesion \\
\hline ENSRNOG00000004335 & $0 \cdot 33$ & & \\
\hline ENSRNOG00000011633 & $-0 \cdot 37$ & a-parvin (Actopaxin; Q9HB97) & Catalytic activity \\
\hline ENSRNOG00000027223 & $-0 \cdot 37$ & & \\
\hline ENSRNOG00000003220 & $-0 \cdot 40$ & Histone H3.3 (P84245) & $\begin{array}{l}\text { DNA binding/chromosome organization } \\
\text { and biogenesis }\end{array}$ \\
\hline ENSRNOG00000018735 & $-0 \cdot 40$ & $\begin{array}{l}\text { H-2 class II histocompatibility antigen } \\
\text { (CD74 antigen; P10247) }\end{array}$ & $\begin{array}{l}\text { Cytokine binding, prostaglandin bio- } \\
\text { synthesis/immune response }\end{array}$ \\
\hline ENSRNOG00000009643 & $-0 \cdot 43$ & $\begin{array}{l}\text { Predicted: RIKEN cDNA 4121402D02 } \\
\quad(\text { XP_239335) }\end{array}$ & \\
\hline ENSRNOG00000017667 & $-0 \cdot 44$ & $\begin{array}{l}\text { Predicted: mKIAA0863 protein } \\
\quad \text { (LOC307236; XM_225732) }\end{array}$ & \\
\hline ENSRNOG00000007628 & $-0 \cdot 44$ & $\begin{array}{l}\text { Predicted: protein tyrosine phosphatase } \\
\text { 4a3 (XP_343260) }\end{array}$ & $\begin{array}{l}\text { Protein tyrosine phosphatase/protein } \\
\text { dephosphorylation }\end{array}$ \\
\hline ENSRNOG00000028530 & $-0 \cdot 47$ & & \\
\hline ENSRNOG00000010266 & $-0 \cdot 62$ & Predicted: RP105 (XP_226731) & \\
\hline ENSRNOG00000016390 & $-0 \cdot 71$ & $\begin{array}{l}\text { Predicted: translation elongation factor } 1 \\
\text { epsilon (XP_214451) }\end{array}$ & \\
\hline ENSRNOG00000023417 & $-0 \cdot 75$ & & \\
\hline ENSRNOG00000017962 & $-0 \cdot 85$ & $\begin{array}{l}\text { Serine/cysteine proteinase inhibitor, } \\
\text { clade B6 (NP_954516) }\end{array}$ & $\begin{array}{l}\text { Serine-type endopeptidase inhibitor } \\
\text { activity }\end{array}$ \\
\hline
\end{tabular}

Detection of 12-lox, furin, calgranulin $B$, and fibulin-1 in blood and uterus by real-time PCR

To investigate whether genes identified by microarray in peripheral blood leukocytes are regulated in other tissues, we examined the effect of $E_{2}$, PPT, and DPN also on their expression in rat uterus by real-time PCR.

The microarray results showed that 12-lox was downregulated in the $\mathrm{E}_{2}$ and DPN groups (Tables 2 and 4). This effect was partly confirmed by real-time PCR, where 12-lox expression was found negatively regulated in leukocytes from the DPN group (Fig. 3A). In addition, a tendency to decrease in the 12-lox mRNA levels was found in the two other treatment groups (Fig. 3A). We observed a stronger down-regulated expression pattern of 12-lox in uterus, when compared with leukocytes. The decrease in the uterine 12-lox mRNA levels was most prominent in the $\mathrm{E}_{2}$ and $\mathrm{PPT}$ groups (Fig. $3 \mathrm{~B}$ ), while in leukocytes, the maximum effect was observed in the DPN group (Fig. 3A).

The furin precursor was found to be down-regulated by all treatments (Tables 2-4). Real-time PCR also showed a tendency to down-regulation by all treatments, but the 
Table 4 Subset of genes regulated by 2,3-bis(4-hydroxyphenyl)-propionitrile in peripheral blood leukocytes

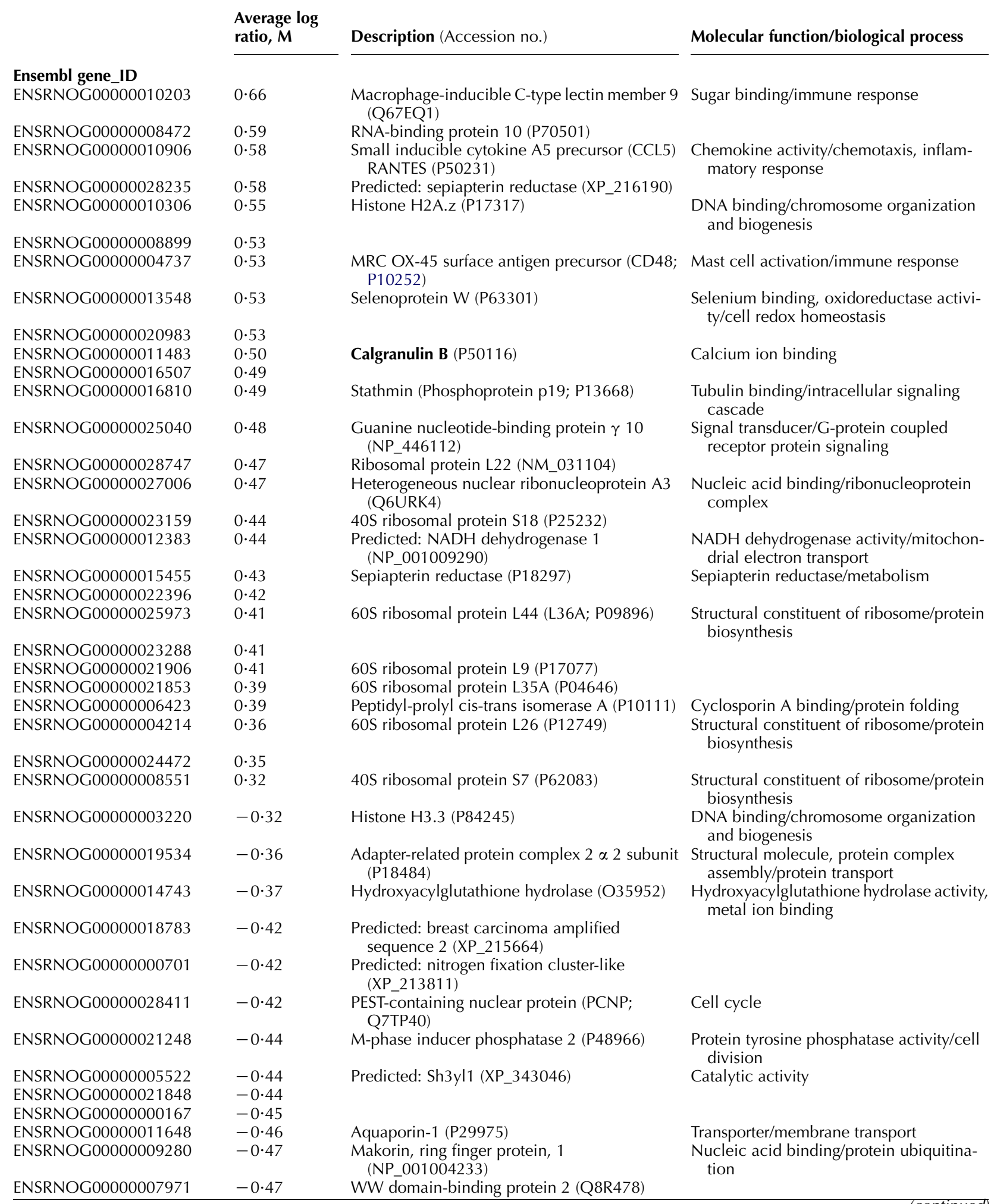


Table 4 Continued

\begin{tabular}{|c|c|c|c|}
\hline & $\begin{array}{l}\text { Average log } \\
\text { ratio, M }\end{array}$ & Description (Accession no.) & Molecular function/biological process \\
\hline ENSRNOG00000021207 & $-0 \cdot 47$ & Predicted: galectin-12 (XP_219545) & Sugar binding \\
\hline ENSRNOG00000007136 & $-0 \cdot 53$ & Annexin A7 (NM_130416) & $\begin{array}{l}\text { Phospholipid binding/regulation of } \\
\text { coagulation }\end{array}$ \\
\hline ENSRNOG00000017640 & $-0 \cdot 55$ & Calcium-binding protein P22 (NM_024139) & Calcium ion binding \\
\hline ENSRNOG00000011352 & $-0 \cdot 56$ & Furin precursor (P23377) & $\begin{array}{l}\text { Calcium ion binding, proteolysis and } \\
\text { peptidolysis/catalytic activity }\end{array}$ \\
\hline ENSRNOG00000017854 & $-0 \cdot 56$ & Mitochondrial uncoupling protein 2 (P56500) & Binding/transport, mitochondrial transport \\
\hline ENSRNOG00000025986 & $-0 \cdot 58$ & & \\
\hline ENSRNOG00000016670 & $-0 \cdot 58$ & $\begin{array}{l}\text { Phosphatidylinositol-4-phosphate 5-kinase, II } \\
\alpha \text { (NM_053926) }\end{array}$ & \\
\hline ENSRNOG00000019366 & $-0 \cdot 65$ & & \\
\hline ENSRNOG00000018000 & $-0 \cdot 68$ & $\begin{array}{l}\text { Predicted: Ran-binding protein } 10 \\
\quad\left(X P \_341677\right)\end{array}$ & Catalytic activity \\
\hline ENSRNOG00000018053 & -0.69 & Predicted: ferrochelatase (XP_341623) & Ferrochelatase activity/heme biosynthesis \\
\hline ENSRNOG00000012206 & $-0 \cdot 72$ & $\begin{array}{l}\text { Predicted: Rab6 interacting protein } 1 \\
\quad\left(X P \_219270\right)\end{array}$ & Nucleic acid binding/catalytic activity \\
\hline ENSRNOG00000006770 & $-0 \cdot 79$ & & \\
\hline ENSRNOG00000015420 & $-0 \cdot 84$ & Syntaxin-binding protein 1 (P61765) & $\begin{array}{l}\text { Vesicle docking during exocytosis/protein } \\
\text { transport }\end{array}$ \\
\hline ENSRNOG00000020951 & $-0 \cdot 90$ & Band 3 anion transport protein (P23562) & $\begin{array}{l}\text { Inorganic anion exchanger activity/anion } \\
\text { transport }\end{array}$ \\
\hline ENSRNOG00000025235 & $-0 \cdot 95$ & LOC304280 protein (Q5RJK4) & Catalytic activity \\
\hline ENSRNOG00000019183 & -0.98 & $\begin{array}{l}\text { Arachidonate 12-lipoxygenase, leukocyte- } \\
\text { type (Q02759) }\end{array}$ & $\begin{array}{l}\text { Lipoxygenase activity/arachidonic acid } \\
\text { metabolism }\end{array}$ \\
\hline
\end{tabular}

effect reached significance only in the DPN-treated group (Fig. 3C). Unlike the negative regulation found in leukocytes (Fig. 3C), we discovered that expression of furin was not affected by any treatment in the uterus, where similar levels of mRNA were observed in all groups (Fig. 3D).

Calgranulin B was found to be up-regulated after DPN treatment (Table 4), but this effect was not verified by realtime PCR (Fig. 3E). The expression in uterus, though, was higher after PPT treatment than in the OvxC- and DPNtreated groups (Fig. 3F).

The fibulin-1 precursor was found to be down-regulated by $E_{2}$ treatment (Table 2). There was a tendency to downregulation of the fibulin-1 mRNA found by PCR (Fig. 4A). Alternative splicing of fibulin-1 may result in four different variants. We investigated the expression of two predominant splice variants of fibulin-1 that can be discriminated by PCR, namely fibulin-1C and fibulin-1D. The expression of fibulin1 variants $\mathrm{C}$ and $\mathrm{D}$ in leukocytes (Fig. $4 \mathrm{C}$ and $\mathrm{E}$ respectively) was similar to the fibulin-1 expression profile (Fig. 4A), but reached significant down-regulation for fibulin-1C after $\mathrm{E}_{2}$ treatment and fibulin-1D after DPN treatment (Fig. 4C and E respectively). Fibulin-1 expression was significantly downregulated by PPT treatment in the uterus (Fig. 4B), which is different to the leukocytes where the tendency to decrease was most pronounced in the $\mathrm{E}_{2}$-treated group (Fig. 4A). Interestingly, we observed a different effect of treatments on the fibulin splicing variants in the uterus: fibulin-1C was induced by DPN, while fibulin-1D was suppressed by PPT (Fig. 4D and F respectively). 

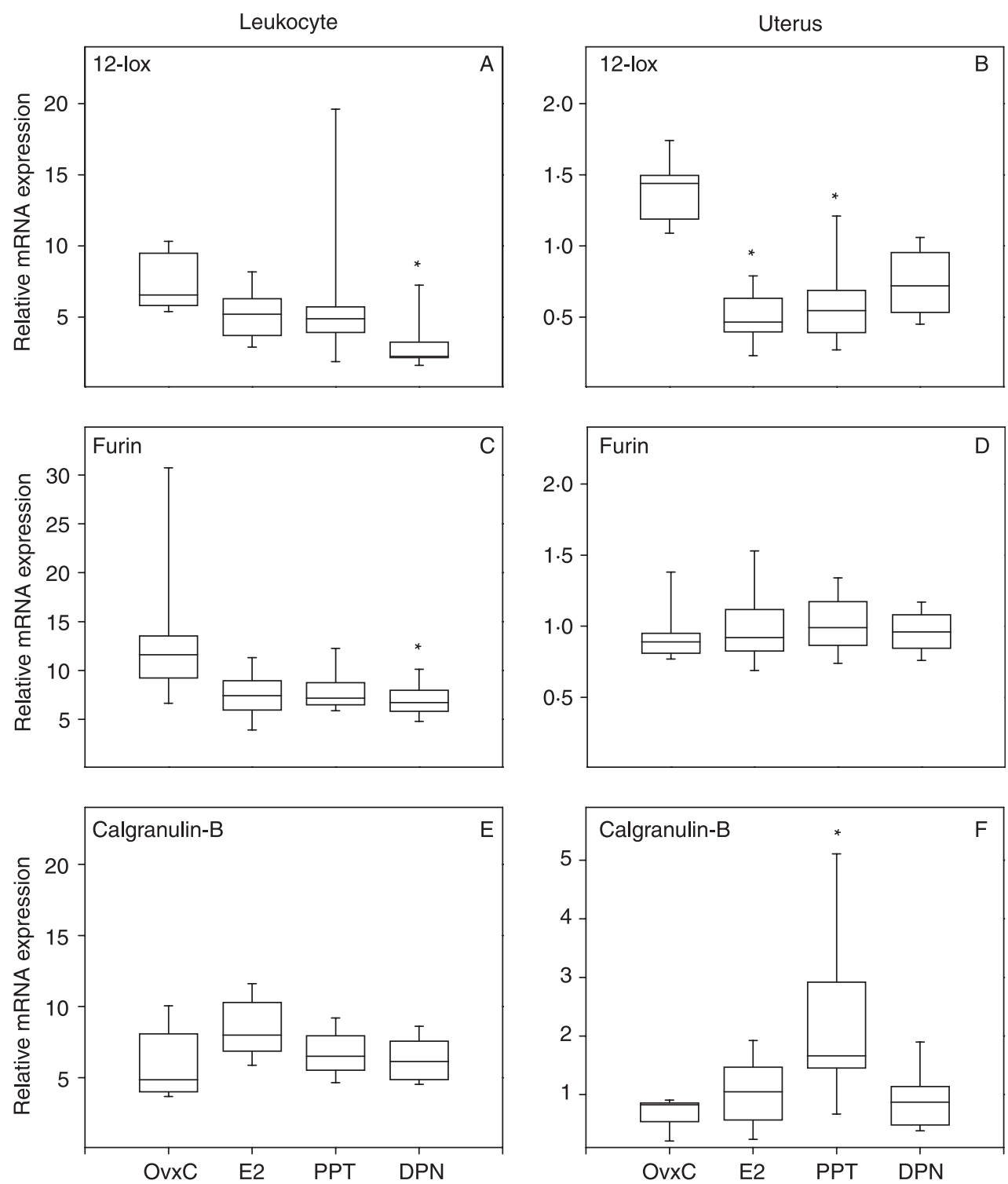

Figure 3 Representative real-time PCR experiments for 12-lox (A and B), furin (C and D), and calgranulin B (E and F) mRNAs expression in peripheral blood leukocytes (left column) and uterus (right column) from rats subjected to treatment with $\mathrm{E}_{2}, \mathrm{PPT}$, and DPN. The values of relative expression of target genes were normalized against HPRT and displayed in arbitrary units. Box and whisker plots represent the median value with $50 \%$ of all data falling within the box. The whiskers extend to the 5th and 95th percentiles. Group medians with asterisk superscripts are significantly different from control (OvxC).

Detection of 12-lox and calgranulin B in blood and uterus by western blot

The protein products of 12-lox and calgranulin B were studied by western blot analysis. The aim was to determine whether the selected regulated genes were also expressed on the protein level in leukocytes and uterus.

The western blot analysis confirmed that the 12-lox protein was present in peripheral blood leukocytes (Fig. 5A). A $60 \mathrm{kDa}$ 12-lox protein was also detected in the uterus (Fig. 5A). The 12-lox protein bands were significantly stronger in the uteri of the PPT group when compared with controls (Fig. 5B).

Calgranulin B was identified in leukocytes as a $14 \mathrm{kDa}$ band, and was also found in the uterus (Fig. 6). The bands were stronger in the uterus after $\mathrm{E}_{2}$ and PPT treatment, whereas they were weak in the control and DPN groups (Fig. 6). 

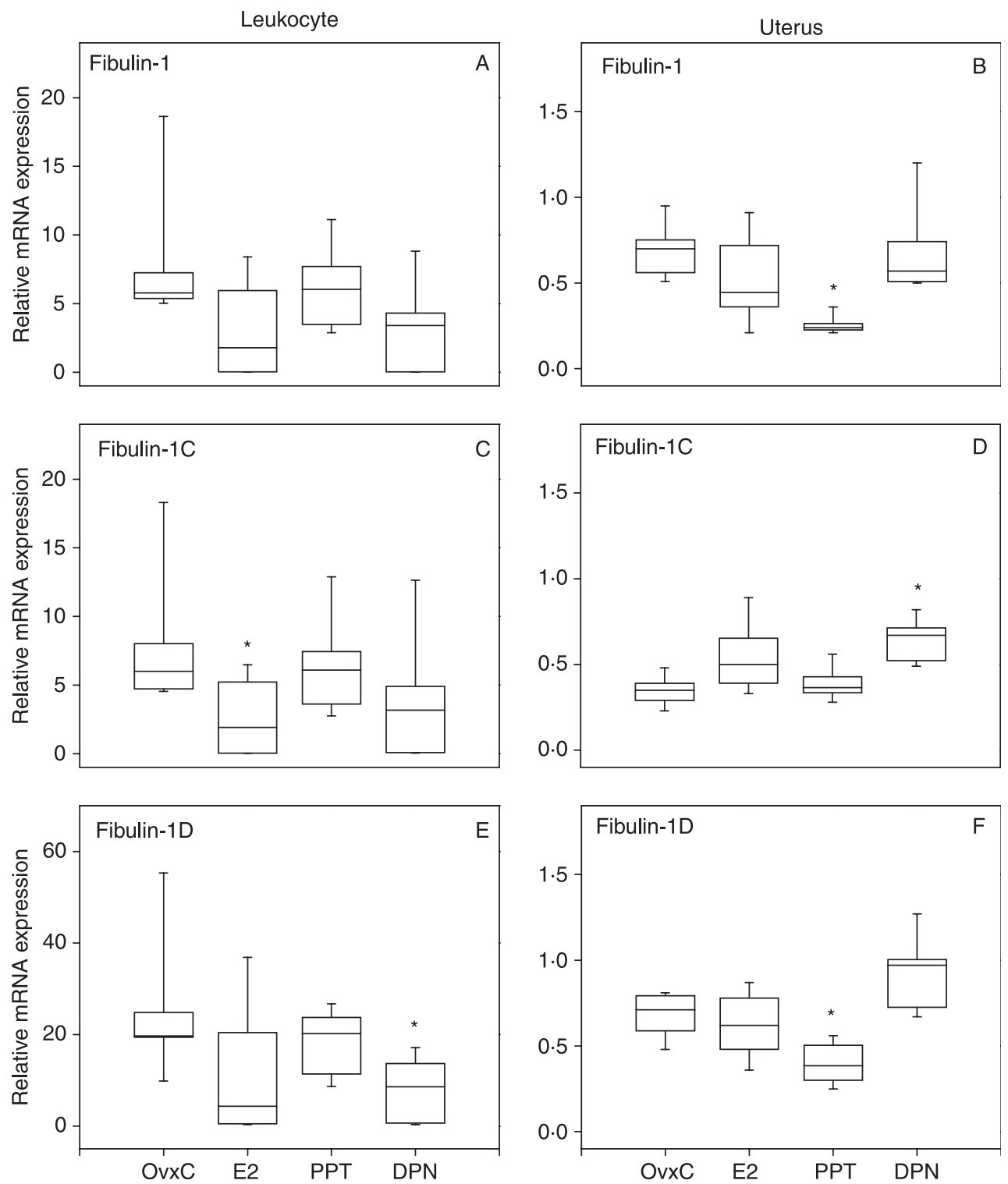

Figure 4 Representative real-time PCR experiments for fibulin-1 (A and B), fibulin-1C (C and D), and fibulin$1 \mathrm{D}$ ( $\mathrm{E}$ and $\mathrm{F}$ ) mRNAs expression in peripheral blood leukocytes (left column) and uterus (right column) from rats subjected to treatment with $\mathrm{E}_{2}, \mathrm{PPT}$, and DPN. The values of relative expression of target genes were normalized against HPRT and displayed in arbitrary units. Box and whisker plots represent the median value with $50 \%$ of all data falling within the box. The whiskers extend to the 5th and 95th percentiles. Group medians with asterisk superscripts are significantly different from control $(\mathrm{OvxC})$.

\section{Discussion}

In this study, we investigated the activity of $\operatorname{ER} \alpha$ and $\operatorname{ER} \beta$ in peripheral blood leukocytes from ovx rats subjected to treatment with $\mathrm{E}_{2}$, PPT, or DPN. Together with $\mathrm{E}_{2}$, a biological agonist on both $\operatorname{ER} \alpha$ and $\operatorname{ER} \beta$, we used the commercially available ER subtype-selective compounds PPT and DPN to highlight possible distinct roles for each $\mathrm{ER}$ isoform in leukocytes.
The recently developed non-steroidal compounds PPT and DPN were characterized as selective agonists for $\operatorname{ER} \alpha$ and ER $\beta$ respectively. PPT is $\sim 1000$-fold potent as an agonist on ER $\alpha$ than on ER $\beta$ and has a 400 -fold preference toward ER $\alpha$ in its binding affinity (Kraichely et al. 2000, Stauffer et al. 2000). DPN acts as an agonist on both ER subtypes, but has a 70 -fold higher relative binding affinity and a 170 -fold higher relative potency in transcription assays with $\operatorname{ER} \beta$ than with ER $\alpha$ (Meyers et al. 2001). 
A

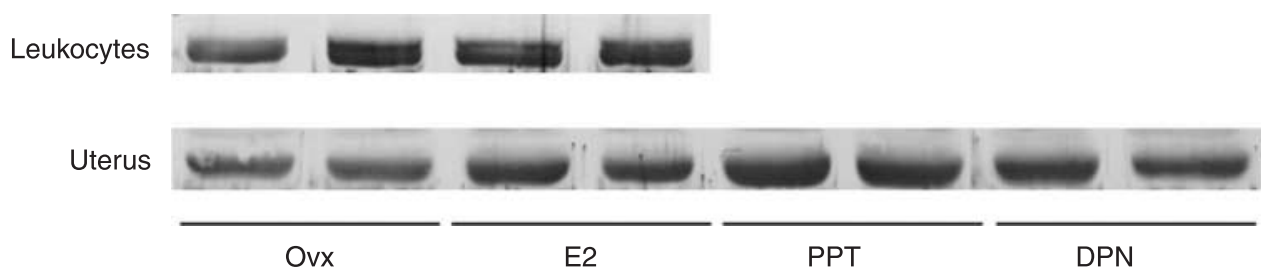

B

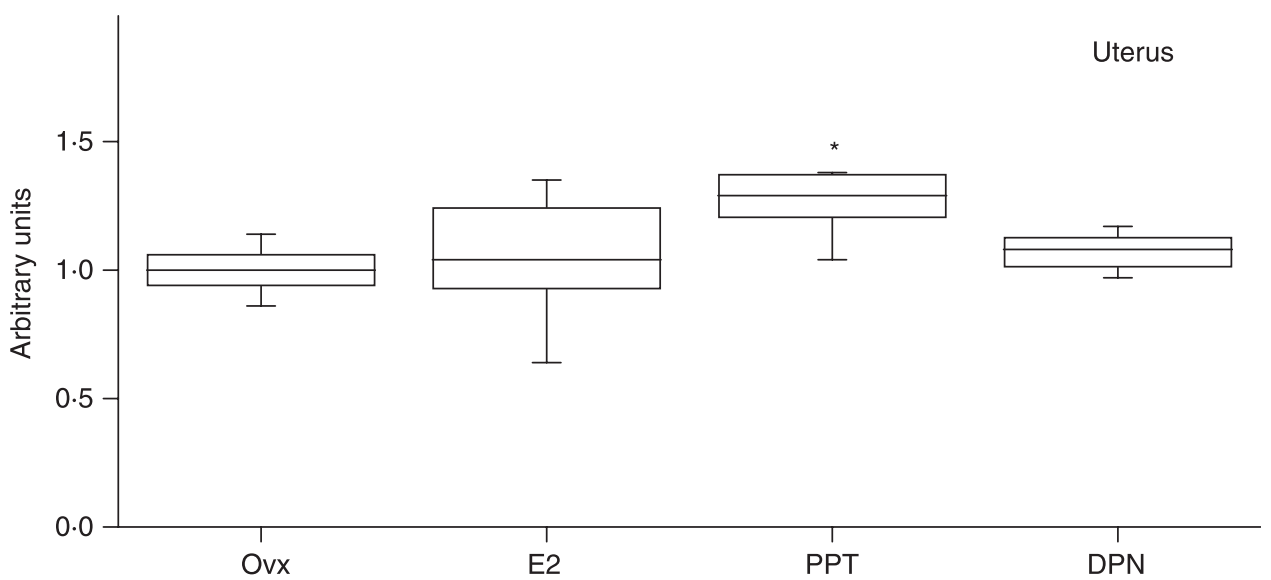

Figure 5 Representative western blot experiments for 12-lox (A) in rat peripheral blood leukocytes and uterus. Proteins were separated by SDS-PAGE and transferred to PVDF membranes, which were incubated with the primary antibody and AP-conjugated secondary antibody. The signal was detected using an AP substrate. The band corresponding to 12-lox is $\sim 60 \mathrm{kDa}$ in size. The bands from all animals were captured by a gel documentation system and used for statistical evaluation of the results (B). The PPT-treated group display stronger protein bands than the control group (B).

Microarray analysis showed that $\mathrm{E}_{2}$ treatment resulted in transcriptional activation or repression of a large number of genes. Some of the genes, such as annexin-1 and $b c l-x$, are known as estrogen-regulated genes (Castro-Caldas et al. 2001, Stoltzner et al. 2001). A few genes, including mitochondrial uncoupling protein 2 and platelet factor 4, which were regulated by $E_{2}$ in our study, have been previously described as estrogen insensitive in other tissues (Norris \& Bonnar 1994, Luukkaa et al. 2001, Stirone et al. 2005). We also detected transcriptional changes in a number of genes, which have not been reported to be estrogen-regulated (leukocyte 12-lox, STAT6, and $\alpha$-parvin). The selective ER $\alpha$ agonist PPT and selective ER $\beta$ agonist DPN produced different effects on gene transcription. The majority of regulated genes were different in the $\mathrm{E}_{2}, \mathrm{PPT}$, and DPN treatment groups, pointing out different roles for $\operatorname{ER} \alpha$ and $\operatorname{ER} \beta$. However, the transcriptional response in the selective agonists' groups was remarkably different when compared with the transcriptional changes in response to $\mathrm{E}_{2}$ (as shown in Fig. 2), which could indicate that mechanisms of gene regulation by PPT and DPN may be substantially different from the mechanism of $\mathrm{E}_{2}$ action. There is a possibility that the treatments themselves
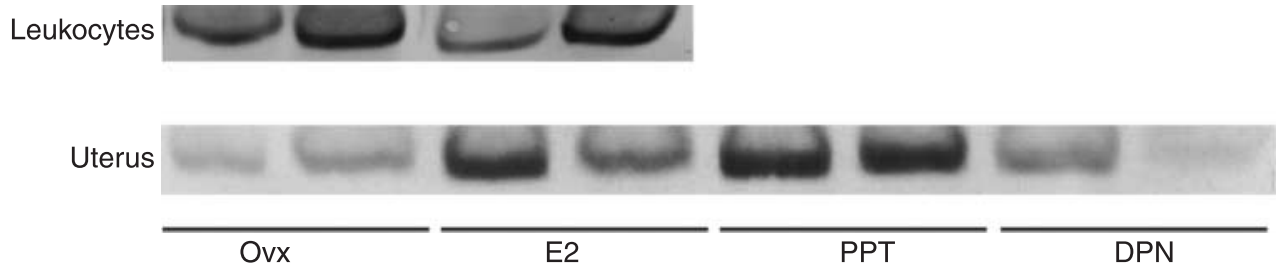

Figure 6 Representative western blot experiments for calgranulin B in rat peripheral blood leukocytes and uterus. Proteins were separated by SDS-PAGE and transferred to PVDF membranes, which were incubated with the respective primary antibodies and AP-conjugated secondary antibody. The signal was detected using an AP substrate. Calgranulin B was detected as a $14 \mathrm{kDa}$ band. In the uterus, the calgranulin B bands from the $\mathrm{E}_{2}$ and PPT treated animals are stronger than those of the control and DPN groups. 
may have had an effect on the leukocyte pool, but due to the short treatment time, this effect would be limited.

Although the genes down-regulated by the three treatments are very different, as can be seen from the Venn diagrams, the functional annotation of the genes is more similar. They all down-regulate genes annotated primarily to categories 'cellular metabolism' and 'primary metabolism'.

From the enrichment analyses, we find that more than 50\% of genes down-regulated by $\mathrm{E}_{2}$ are related to 'binding' or 'cellular physiological processes', most significant are the enrichment of genes related to 'oxygen and reactive oxygen species metabolism' as well as 'response to oxidative stress'. In previous studies, we have shown that estrogens regulate expression of thioredoxin in rats (Sahlin et al. 1997a) and that thioredoxin and glutaredoxin mRNAs varies in human cervix and endometrium in relation to pregnancy and menstrual phase (Sahlin et al. 1997b, Stavréus-Evers et al. 2002). In pregnancies where prostaglandin $\mathrm{E}_{2}$ was used to induce cervical ripening, glutaredoxin mRNA level was particularly increased (Sahlin et al. 1997b). In later studies, we have found that prostaglandin treatment induces leukocyte influx in the cervix (L Sahhin, Y Stjernholm-Vladic and G EkmanOrdeberg, unpublished observations) and why the leukocytes might be the source of the glutaredoxin. Thus, the ERs in the leukocytes could mediate the increased glutaredoxin expression.

The enrichment analyses also showed that by DPN treatment the down-regulated genes were $56 \%$ related to 'intracellular' and that the most significantly changed genes were related to the Golgi network. Genes that were most significantly up-regulated by DPN related primarily to terms including 'ribosome' which could indicate that $\mathrm{ER} \beta$ binding increases transcription. The up-regulated genes after DPN treatment were close to $30 \%$ related to 'immune response'. This finding could have impact on the sex difference and estrogen dependence found in morbidity and prevalence of autoimmune diseases (Druckmann 2001, Whitacre 2001).

Our study shows less overlap between genes regulated via $\mathrm{ER} \alpha$ or ER $\beta$ than has been previously reported. Using the osteoblast-like cell line (U2OS) stably transfected with either ER $\alpha$ or ER $\beta$, Stossi et al. (2004) demonstrated that $61 \%$ of all $E_{2}$-regulated genes were commonly regulated via $E R \alpha$ and $E R \beta$. The difference in the proportion of commonly regulated genes does not seem to be dependent on the type of cells, as other groups studying the effect of $\mathrm{E}_{2}$ on $\mathrm{U} 2 \mathrm{OS}$ cell line reported only $17-21 \%$ of genes being commonly regulated via $\mathrm{ER} \alpha$ and $\operatorname{ER} \beta$ (Monroe et al. 2003, Kian Tee et al. 2004). The discrepancy may rather depend on experimental design and other variables such as duration of treatment.

In contrast to those studies, we investigated genes regulated by $\mathrm{ER} \alpha$ and $\mathrm{ER} \beta$ in vivo in different cell types expressing either one or both subtypes of ER. Interpretation of the results may be complicated because peripheral blood leukocytes contain several types of cells. Nevertheless, we deliberately avoided isolation of one or several cell types in order to be able to perform the analysis under true in vivo conditions. Thus, in the current study, no additional ex vivo procedures, such as incubations and density gradient centrifugations, were performed. These procedures have been shown to change gene expression pattern dramatically (Riches et al. 1992, Hartel et al. 2001). Instead, we stabilized RNA immediately on blood collection, allowing accurate in vivo investigation of gene expression profile in leukocytes, as most of the mRNA in whole blood is considered to originate from leukocytes. A disadvantage with using whole blood RNA is that it may contain relatively high amounts of globin mRNA, which may reduce the sensitivity of microarray analysis.

For validation of microarray results, we chose four genes that are considered to be involved in ECM remodeling and inflammatory response. These genes were arachidonate 12-lox, fibulin-1, furin, and calgranulin B. Leukocyte type 12-lox of the rat is similar to human 15-lox. Arachidonate 12-lox has enzymatic activity and is involved in one of the two major metabolic pathways (lipoxygenase and cyclooxygenase) of arachidonic acid. As the 12-lox products are present on the site of inflammation, this enzyme was previously believed to exhibit pro-inflammatory activities (reviewed in Yoshimoto \& Takahashi 2002). In recent years, several lines of experimental evidence suggest that 12-lox products might also exhibit antiinflammatory properties (Levy et al. 2001, Vachier et al. 2002, Serhan et al. 2003). Increased concentrations of arachidonic acid 12-lox metabolites (12-hydroxyeicosatetraenoic acid, leukotriene B4) are observed in amniotic fluid during parturition suggesting a role in active labor (Romero et al. 1987). Moreover, 12-lox metabolites may be involved in the ECM remodeling as suggested by increased production of fibronectin and collagens in certain cell lines overexpressing 12-lox (Wen et al. 2003).

In our study, the effect of the treatments on 12-lox expression was different in the leukocytes when compared with the uterus. The negative regulation of uterine 12-lox mRNA was most prominent in the $\mathrm{E}_{2}$ and PPT groups, while in the leukocytes, the greatest decrease was found in the DPN-treated group. Assuming that the 12-lox expression is regulated via $E R \alpha$ and $E R \beta$ in a similar manner, the variation between responses to the selective agonists in different tissues may depend on differences in the ratio of $\operatorname{ER} \alpha / E R \beta$. It is recognized that the uterine tissue expresses predominantly $\mathrm{ER} \alpha$, while $\mathrm{ER} \beta$ is thought to be the dominating subtype in leukocytes (Wang et al. 1999, Stygar et al. 2001). It is striking though that the 12-lox protein is up-regulated by ER $\alpha$ activity in the uterus as determined by western blot. The rationale for this is not known, but post-transcriptional regulation seems to be more powerful than the transcriptional regulation of the gene expression itself.

Another gene selected for validation was fibulin-1. Fibulins are a family of proteins associated with basement membranes and elastic ECM fibers (reviewed in Argraves et al. 2003). They are hypothesized to function as intra-molecular bridges that stabilize the organization of supra-molecular ECM 
structures. Fibulin-1 is a cofactor of the ADAMTS-1 metalloprotease which is active in proteolysis of the proteoglycan versican, thus involved in ECM remodeling (Kern et al. 2006). Fibulin-1 shows fibronectin- and integrinbinding properties and the level of this protein in the endometrium fluctuates during the menstrual cycle. It has been demonstrated that fibulin-1 is regulated by sex steroid hormones. Haendler et al. (2004) reported that the fibulin-1 gene in human endometrium is regulated both by estrogen and progesterone and that the effect appears to be cell-type specific. $E_{2}$ induced fibulin-1 in endometrial glands, while the inductive effect of progesterone was observed in the endometrial stroma. In ER-positive ovarian and breast cancer cell lines, fibulin-1 mRNA levels are markedly increased by estrogens. Transfection experiments using fibulin-1 promoter constructs demonstrated that $\mathrm{E}_{2}$ increases fibulin-1 gene transcription and that $\mathrm{ER} \alpha$ is more potent than $\operatorname{ER} \beta$ to mediate $\mathrm{E}_{2}$ regulation of the transfected fibulin-1 promoter (Bardin et al. 2005). In our study, fibulin-1 was identified among genes down-regulated by $\mathrm{E}_{2}$ in leukocytes and this finding was consistent when validated with real-time PCR. In the uterus, we report differential regulation of fibulin-1 splice variants $C$ and $D$ by the selective $\operatorname{ER} \alpha$ and $\operatorname{ER} \beta$ agonists. Induction of fibulin-1C by DPN is contrasted by suppression of fibulin-1D by PPT, suggesting that the transcriptional effect of $\operatorname{ER} \beta$ opposes the effect of $\operatorname{ER} \alpha$. It is obvious that the fibulin-1 gene is under hormonal control, but the exact mechanism of regulation and function of this protein in the ECM need further studies.

Furin was identified among regulated genes by the microarray and selected for further analysis. Furin is one of the proteolytic enzymes activating MMP zymogens (Verma \& Hansch 2007), and thus involved in ECM remodeling. Furin is a calcium-dependent serine protease of the subtilisin-like pro-protein convertase family. This transmembrane glycoprotein catalyses the maturation of a very diverse group of bioactive proteins, ranging from growth factors and receptors to pathogen proteins (reviewed in Molloy et al. 1999). Furin is also efficient at cleaving several adhesion-related proteins involved in cell-ECM interactions. In addition, furin processes protein substrates such as pro-membrane-type-1 MMPs (proMT1-MMP) and pro-transforming-growth-factor $\beta$, which play important roles in the remodeling of ECM and basement membranes (Dubois et al. 1995, Sato et al. 1996). We demonstrate that gene expression of furin in leukocytes is negatively regulated by estrogenic substances, with the most profound effect found in the DPN treatment group. No effect was found on the furin expression in the uterus. Once again, our differing results between leukocytes and uterus could depend on the dominant ER subtype present, i.e. ER $\beta$ in leukocytes and ER $\alpha$ in uterus (Wang et al. 1999, Stygar et al. 2001).

Calgranulin $B$ (MRP14 or S100A9) is a potent stimulator of neutrophils and the protein is suggested to be involved in neutrophil migration to inflammatory sites
(Ryckman et al. 2003) and it is also a substrate for MMP2 and MMP-9 (Greenlee et al. 2006), and thus likely to be involved in ECM remodeling. Calgranulin B is the major calcium-binding protein of neutrophils and monocytes (Vogl et al. 2004), and stimulates proliferation of fibroblasts, suggesting that it plays a role in chronic inflammation (Shibata et al. 2004). The cellular properties of calgranulin B, its spatial localization, and dramatic increase in cervix and myometrium of women in labor suggest that this protein may be very important in the initiation or propagation of human labor (Havelock et al. 2005). In contrast to that, studies of MRP-14(-/-) mice showed that they have no obvious phenotype and are fertile (Hobbs et al. 2003). Our data on calgranulin B regulation in leukocytes by DPN treatment as found by the microarray were not confirmed by real-time PCR, although there was a tendency toward increasing levels after estrogen treatment. In the uterus, however, the level was up-regulated by PPT treatment. By western blot, we found varying calgranulin $B$ protein levels in the leukocytes, both in controls and after $\mathrm{E}_{2}$ treatment. Though, in the uterus, $\mathrm{E}_{2}$ and PPT treatment seemed to increase the protein level, indicating regulation via predominantly $\mathrm{ER} \alpha$, well in agreement with the PCR results.

The selected genes were often differently regulated comparing leukocytes and uterus from the same animals. The transcription is regulated by enhancers and repressors (co-regulators), which may differ depending on the cell type and tissue (O'Malley 2007). Thus, gene regulation by receptor activation is regulated by far more factors than the actual ligand, and these co-regulators will modify the effect due to tissue and cell type.

Our data describe gene expression profiles measured at a single time point and after a single dose of treatment. Thus, it is possible that additional forms of gene regulation may arise if other doses and time points are used.

Two of the selected genes were also analyzed on a protein level and were both detected in the leukocytes by western blot. The changes in the protein levels of 12-lox in uterus did not follow the gene regulation pattern. A possible explanation to the discrepancy between mRNA and protein levels is that many other genes are regulated by ER activation and some of these gene products could affect protein stability and turnover rate.

In recent years, studies have shown evidence for both pro- and anti-inflammatory activities of estrogens. The key cells in the inflammatory reaction are leukocytes. Our study demonstrates that peripheral blood leukocytes are responsive to estrogens. $E_{2}$ and the selective $E R \alpha$ and ER $\beta$ agonists regulate a number of genes that may contribute to remodeling of ECM and inflammation. The effect on mRNA levels is predominantly negative suggesting that pro-inflammatory and catabolic activities of leukocytes are likely to be reduced by estrogens. On the other hand, the impression from protein levels of the same gene products implies that the protein does not 
always reflect the effect on the mRNA level. Thus, the final effect from estrogen treatment is multi-regulated; directly on the gene expression level, on the posttranscriptional level and possibly also indirectly, via other proteins. This could be a major reason for the various effects from estrogen treatment that has been presented, the multitude in regulatory effects depend on dose, time, administration method, and cell or tissue type studied.

\section{Acknowledgements}

We thank Prof. Gunnar Norstedt at the Center for Molecular Medicine at Karolinska Institutet for lending us real-time PCR equipment for this study, and KIChip microarray core facility at Karolinska Institutet for performing the microarray analysis. We further thank ArrayAdvice (www.arrayadvice.com) for assistance with the functional analyses of the differently expressed genes. This study received financial support from The Swedish Research Council (project 73X-20137), The Swedish Society of Medicine (L S), Sigurd and Elsa Goljes foundation (D S), and Karolinska Institutet. The authors declare that there is no conflict of interest would prejudice the impartiality of this scientific work.

\section{References}

An J, Ribeiro RC, Webb P, Gustafsson JA, Kushner PJ, Baxter JD \& Leitman DC 1999 Estradiol repression of tumor necrosis factor-alpha transcription requires estrogen receptor activation function- 2 and is enhanced by coactivators. PNAS 96 15161-15166.

Argraves WS, Greene LM, Cooley MA \& Gallagher WM 2003 Fibulins: physiological and disease perspectives. EMBO Reports 4 1127-1131.

Bardin A, Moll F, Margueron R, Delfour C, Chu ML, Maudelonde T, Cavailles V \& Pujol P 2005 Transcriptional and posttranscriptional regulation of fibulin-1 by estrogens leads to differential induction of messenger ribonucleic acid variants in ovarian and breast cancer cells. Endocrinology 146 760-768.

Benjamini Y \& Hochberg Y 1995 Controlling the false discovery rate: a practical and powerful approach to multiple testing. Journal of the Royal Statistical Society. Series B $\mathbf{5 7}$ 289-300.

Bokström H, Brännström M, Alexandersson M \& Norström A 1997 Leukocyte subpopulations in the human uterine cervical stroma at early and term pregnancy. Human Reproduction 12 586-590.

Castro-Caldas M, Duarte CB, Carvalho AR \& Lopes MC 2001 17ß-Estradiol promotes the synthesis and the secretion of annexin I in the CCRF-CEM human cell line. Mediators of Inflammation 10 245-251.

Diel P 2002 Review: tissue-specific estrogenic response and molecular mechanisms. Toxicology Letters 127 217-224.

Druckmann R 2001 Review: female sex hormones, autoimmune diseases and immune response. Gynecological Endocrinology 15 (Suppl 6) 69-76.

Dubois CM, Laprise MH, Blanchette F, Gentry LE \& Leduc R 1995 Processing of transforming growth factor beta 1 precursor by human furin convertase. Journal of Biological Chemistry 270 10618-10624.

Elloso MM, Phiel K, Henderson RA, Harris HA \& Adelman SJ 2005 Supression of experimental autoimmune encephalomyelitis using estrogen receptor-selective ligands. Journal of Endocrinology 185 243-252.
Enmark E, Pelto-Huikko M, Grandien K, Lagercrantz S, Lagercrantz J, Fried G, Nordenskjold M \& Gustafsson JA 1997 Human estrogen receptor beta-gene structure, chromosomal localization, and expression pattern. Journal of Clinical Endocrinology and Metabolism 82 4258-4265.

Follettie MT, Pinard M, Keith JC, Wang L, Chelsky D, Hayward C, Kearney P, Thibault P, Paramithiotis E, Doner AJ et al. 2006 Organ messenger ribonucleic acid and plasma proteome changes in the adjuvant-induced arthritis model: responses to disease induction and therapy with estrogen receptor- $\beta$ selective agonist ERB-041. Endocrinology 147 714-723.

Frasor J, Barnett DH, Danes JM, Hess R, Parlow AF \& Katzenellenbogen BS 2003 Response-specific and ligand dose-dependent modulation of estrogen receptor (ER) alpha activity by ERbeta in the uterus. Endocrinology 144 3159-3166.

Greenlee KJ, Corry DB, Engler DA, Matsunami RK, Tessier P, Cook RG, Werb Z \& Kheradmand F 2006 Proteomic identification of in vivo substrates for matrix metalloproteinases 2 and 9 reveals a mechanism for resolution of inflammation. Journal of Immunology 177 7312-7321.

Haendler B, Yamanouchi H, Lessey BA, Chwalisz K \& Hess-Stumpp H 2004 Cycle-dependent endometrial expression and hormonal regulation of the fibulin-1 gene. Molecular Reproduction and Development 68 279-287.

Harrington WR, Sheng S, Barnett DH, Petz LN, Katzenellenbogen JA \& Katzenellenbogen B 2003 Activities of estrogen receptor alpha- and betaselective ligands at diverse estrogen responsive gene sites mediating transactivation or transrepression. Molecular and Cellular Endocrinology 206 $13-22$.

Harris HA, Katzenellenbogen JA \& Katzenellenbogen BS 2002 Characterization of the biological roles of the estrogen receptors, ERalpha and ERbeta, in estrogen target tissues in vivo through the use of an ERalphaselective ligand. Endocrinology 143 4172-4177.

Hartel C, Bein G, Muller-Steinhardt M \& Kluter H 2001 Ex vivo induction of cytokine mRNA expression in human blood samples. Journal of Immunological Methods 249 63-71.

Havelock JC, Keller P, Muleba N, Mayhew BA, Casey BM, Rainey WE \& Word RA 2005 Human myometrial gene expression before and during parturition. Biology of Reproduction 72 707-719.

Hildebrand F, Hubbard WJ, Choudhry MA, Thobe BM, Pape H-C \& Chaudry IH 2006 Effects of $17 \beta$-estradiol and flutamide on inflammatory response and distant organ damage following traumahemmorrhage in metestrus females. Journal of Leukocyte Biology $\mathbf{8 0}$ 759-765.

Hobbs JA, May R, Tanousis K, McNeill E, Mathies M, Gebhardt C, Henderson R, Robinson MJ \& Hogg N 2003 Myeloid cell function in MRP-14 (S100A9) null mice. Molecular and Cellular Biology 23 2564-2576.

Hosack DA, Dennis G Jr, Sherman BT, Lane HC \& Lempicki RA 2003 Identifying biological themes within lists of genes with EASE. Genome Biology 4 R70.

Kern CB, Twal WO, Mjaatvedt CH, Fairey SE, Toole BP, Iruela-Arispe ML \& Argraves WS 2006 Proteolytic cleavage of versican during cardiac cushion morphogenesis. Developmental Dynamics 235 2238-2247.

Kian Tee M, Rogatsky I, Tzagarakis-Foster C, Cvoro A, An J, Christy RJ, Yamamoto KR \& Leitman DC 2004 Estradiol and selective estrogen receptor modulators differentially regulate target genes with estrogen receptors alpha and beta. Molecular Biology of the Cell $\mathbf{1 5}$ $1262-1272$.

Kraichely DM, Sun J, Katzenellenbogen JA \& Katzenellenbogen BS 2000 Conformational changes and coactivator recruitment by novel ligands for estrogen receptor-alpha and estrogen receptor-beta: correlations with biological character and distinct differences among SRC coactivator family members. Endocrinology 141 3534-3545.

Lang TJ 2004 Estrogen as an immunomodulator. Clinical Immunology 113 224-230.

Lee GS, Kim HJ, Jung YW, Choi KC \& Jeung EB 2005 Estrogen receptor alpha pathway is involved in the regulation of Calbindin-D9k in the uterus of immature rats. Toxicological Science 84 270-277. 
Levy BD, Clish CB, Schmidt B, Gronert K \& Serhan CN 2001 Lipid mediator class switching during acute inflammation: signals in resolution. Nature Immunology 2 612-619.

Li J \& McMurray RW 2006 Effects of estrogen receptor subtype-selective agonists on immune functions in ovariectomized mice. International Immunopharmacology 6 1413-1423.

Liggins GC 1981 Cervical ripening as an inflammatory reaction. In The Cervix in Pregnancy and Labour, Clinical and Biochemical Investigation, pp 1-9. Eds DA Ellwood \& ABM Anderson. Edinburgh, UK: Churchill Livingstone.

Lowry OH, Rosebrough NJ, Farr AL \& Randall RJ 1951 Protein measurement with the Folin phenol reagent. Journal of Biological Chemistry $193265-275$

Luukkaa V, Savontaus E, Rouru J, Virtanen KA, Boss O, Huhtaniemi I, Koulu M, Pesonen U \& Huupponen R 2001 Effects of estrous cycle and steroid replacement on the expression of leptin and uncoupling proteins in adipose tissue in the rat. Gynecological Endocrinology 15 103-112.

McCrohon JA, Nakhla S, Jessup W, Stanley KK \& Celermajer DS 1999 Estrogen and progesterone reduce lipid accumulation in human monocyte-derived macrophages: a sex-specific effect. Circulation 100 2319-2325.

McDonnell DP 2006 Mechanism-based discovery as an approach to identify the next generation of estrogen receptor modulators. FASEB Journal 20 2432-2434.

McKenna NJ, Lanz RB \& O'Malley BW 1999 Nuclear receptor coregulators: cellular and molecular biology. Endocrine Reviews 20 321-344.

Meyers MJ, Sun J, Carlson KE, Marriner GA, Katzenellenbogen BS \& Katzenellenbogen JA 2001 Estrogen receptor-beta potency-selective ligands: structure-activity relationship studies of diarylpropionitriles and their acetylene and polar analogues. Journal of Medicinal Chemistry 44 4230-4251.

Molero L, Garcia-Duran M, Diaz-Recasens J, Rico L, Casado S \& LopezFarre A 2002 Expression of estrogen receptor subtypes and neuronal nitric oxide synthase in neutrophils from women and men: regulation by estrogen. Cardiovascular Research 56 43-51.

Molloy SS, Anderson ED, Jean F \& Thomas G 1999 Bi-cycling the furin pathway: from TGN localization to pathogen activation and embryogenesis. Trends in Cell Biology 9 28-35.

Monroe DG, Getz BJ, Johnsen SA, Riggs BL, Khosla S \& Spelsberg TC 2003 Estrogen receptor isoform-specific regulation of endogenous gene expression in human osteoblastic cell lines expressing either ERalpha or ERbeta. Journal of Cellular Biochemistry 90 315-326.

Norris LA \& Bonnar J 1994 Effect of oestrogen dose on whole blood platelet activation in women taking new low dose oral contraceptives. Thrombosis and Haemostasis $\mathbf{7 2}$ 926-930.

O'Malley BW 2007 Coregulators: from whence came these 'master genes'. Molecular Endocrinology 21 1009-1013.

Osman I, Young A, Ledingham MA, Thomson AJ, Jordan F, Greer IA \& Norman JE 2003 Leukocyte density and pro-inflammatory cytokine expression in human fetal membranes, decidua, cervix and myometrium before and during labour at term. Molecular Human Reproduction 9 41-45.

Osmers R, Rath W, Adelmann-Grill BC, Fittkow C, Kuloczik M, Szeverenyi M, Tschesche H \& Kuhn W 1992 Origin of cervical collagenase during parturition. American Journal of Obstetrics and Gynecology 166 1455-1460.

Paech K, Webb P, Kuiper GG, Nilsson S, Gustafsson J, Kushner PJ \& Scanlan TS 1997 Differential ligand activation of estrogen receptors ERalpha and ERbeta at AP1 sites. Science 277 1508-1510.

Riches P, Gooding R, Millar BC \& Rowbottom AW 1992 Influence of collection and separation of blood samples on plasma IL-1, IL-6 and TNF-alpha concentrations. Journal of Immunological Methods $\mathbf{1 5 3}$ 125-131.

Romero R, Emamian M, Wan M, Grzyboski C, Hobbins JC \& Mitchell MD 1987 Increased concentrations of arachidonic acid lipoxygenase metabolites in amniotic fluid during parturition. Obstetrics and Gynecology 70 849-851.
Ryckman C, Vandal K, Rouleau P, Talbot M \& Tessier PA 2003 Proinflammatory activities of S100: proteins S100A8, S100A9, and S100A8/A9 induce neutrophil chemotaxis and adhesion. Journal of Immunology 170 3233-3242.

Sahlin L, Holmgren A \& Eriksson H 1997a Thioredoxin messenger ribonucleic acid is regulated by estradiol in the rat uterus. Biology of Reproduction 57 1056-1059.

Sahlin L, Stjernholm Y, Holmgren A, Ekman G \& Eriksson H 19976 The expression of thioredoxin mRNA is increased in the human cervix during pregnancy. Molecular Human Reproduction 3 1113-1117.

Sato H, Kinoshita T, Takino T, Nakayama K \& Seiki M 1996 Activation of a recombinant membrane type 1-matrix metalloproteinase (MT1-MMP) by furin and its interaction with tissue inhibitor of metalloproteinases (TIMP)2. FEBS Letters 393 101-104.

Serhan CN, Jain A, Marleau S, Clish C, Kantarci A, Behbehani B, Colgan SP, Stahl GL, Merched A, Petasis NA et al. 2003 Reduced inflammation and tissue damage in transgenic rabbits overexpressing 15-lipoxygenase and endogenous anti-inflammatory lipid mediators. Journal of Immunology 171 6856-6865.

Shibata F, Miyama K, Shinoda F, Mizumoto J, Takano K \& Nakagawa H 2004 Fibroblast growth-stimulating activity of S100A9 (MRP-14). European Journal of Biochemistry 271 2137-2143.

Smyth GK 2004 Linear models and empirical Bayesmethods for assessing differential expression inmicroarray experiments. Statistical Applications in Genetics and Molecular Biology 3 (Article 3).

Stauffer SR, Coletta CJ, Tedesco R, Nishiguchi G, Carlson K, Sun J, Katzenellenbogen BS \& Katzenellenbogen JA 2000 Pyrazole ligands: structure-affinity/activity relationships and estrogen receptor-alphaselective agonists. Journal of Medicinal Chemistry 43 4934-4947.

Stavréus-Evers A, Masironi B, Landgren B-M, Holmgren A, Eriksson H \& Sahlin L 2002 Immunohistochemical localization of glutaredoxin and thioredoxin in human endometrium: a possible relation to pinopods. Molecular Human Reproduction 8 546-551.

Stirone C, Duckles SP, Krause DN \& Procaccio V 2005 Estrogen increases mitochondrial efficiency and reduces oxidative stress in cerebral blood vessels. Molecular Pharmacolog 68 959-965.

Stoltzner SE, Berchtold NC, Cotman CW \& Pike CJ 2001 Estrogen regulates bcl-x expression in rat hippocampus. Neuroreport 12 27972800.

Stossi F, Barnett DH, Frasor J, Komm B, Lyttle CR \& Katzenellenbogen BS 2004 Transcriptional profiling of estrogen-regulated gene expression via estrogen receptor $(E R)$ alpha or $E R$ beta in human osteosarcoma cells: distinct and common target genes for these receptors. Endocrinology 145 3473-3486.

Stygar D, Wang H, Stjernholm Vladic Y, Ekman G, Eriksson H \& Sahlin L 2001 Co-localization of oestrogen receptor beta and leukocyte markers in the human cervix. Molecular Human Reproduction 7 881-886.

Stygar D, Wang H, Stjernholm Vladic Y, Ekman G, Eriksson H \& Sahlin L 2002 Increased level of matrix metalloproteinases 2 and 9 in the ripening process of the human cervix. Biology of Reproduction $\mathbf{6 7}$ 889-894.

Stygar D, Westlund P, Eriksson H \& Sahlin L 2006 Identification of wild type and variants of oestrogen receptors in polymorphonuclear and mononuclear leucocytes. Clinical Endocrinology 64 74-81.

Vachier I, Chanez P, Bonnans C, Godard P, Bousquet J \& Chavis C 2002 Endogenous anti-inflammatory mediators from arachidonate in human neutrophils. Biochemical and Biophysical Research Communications 290 219-224.

Verma RP \& Hansch C 2007 Matrix metalloproteinases (MMPs): chemicalbiological functions and (Q)SARs. Bioorganic and Medicinal Chemistry 15 2223-2268.

Vogl T, Ludwig S, Goebeler M, Strey A, Thorey IS, Reichelt R, Foell D, Gerke V, Manitz MP, Nacken W et al. 2004 MRP8 and MRP14 control microtubule reorganization during transendothelial migration of phagocytes. Blood 104 4260-4268.

Wang H, Masironi B, Eriksson H \& Sahlin L 1999 A comparative study of estrogen receptors alpha and beta in the rat uterus. Biology of Reproduction 61 955-964. 
Wen Y, Gu J, Peng X, Zhang G \& Nadler J 2003 Overexpression of 12-lipoxygenase and cardiac fibroblast hypertrophy. Trends in Cardiovascular Medicine 13 129-136.

Whitacre CC 2001 Sex differences in autoimmune disease. Nature Immunology 2 777-780.

Yang YH, Dudoit S, Luu P, Lin DM, Peng V, Ngai J \& Speed TP 2002 Normalization for cDNA microarray data: a robust composite method addressing single and multiple slide systematic variation. Nucleic Acids Research 30 e15.
Yoshimoto T \& Takahashi Y 2002 Arachidonate 12-lipoxygenases. Prostaglandins and Other Lipid Mediators 68-69 245-262.

Received in final form 22 March 2007

Accepted 23 April 2007

Made available online as an Accepted Preprint 24 April 2007 